\title{
Localization of telomerase hTERT protein in frozen sections of basal cell carcinomas (BCC) and tumor margin tissues
}

\author{
EVA-MARIA FABRICIUS ${ }^{1}$, UTE KRUSE-BOITSCHENKO ${ }^{1}$, REEM KHOURY $^{1}$, \\ GUSTAV-PAUL WILDNER $^{2}$, JAN-DIRK RAGUSE ${ }^{1}$, MARTIN KLEIN ${ }^{1}$ and BODO HOFFMEISTER ${ }^{1}$ \\ ${ }^{1}$ Clinic for Oral and Maxillofacial Surgery, Campus Virchow Hospital; ${ }^{2}$ formerly Department of Pathology, \\ Robert-Rössle-Clinic, Campus Berlin-Buch, Charité - Universitätsmedizin Berlin, Germany
}

Received June 16, 2009; Accepted August 7, 2009

DOI: 10.3892/ijo_00000456

\begin{abstract}
In previous studies we demonstrated telomerase activity in frozen tissues from BCC and their tumor-free margins by the PCR ELISA. In this study we examined in the same frozen sections immunohistochemical presence of hTERT in the nucleus. After fixation in acetone and methanol followed by steaming we used for visualization the antigenantibody reactions by APAAP. This was the best method of preparation of the frozen sections in our preliminary hTERT-study with squamous cell carcinomas. This study was supplemented with antibodies against $\mathrm{Ki}-67$, nucleolin, common leucocyte antigen CD45 and mutated p53. The immunoreactive scores were determined and included the comparison with telomerase activity. The investigation of hTERT expression was performed in the tissues of 41 patients with BCC and control tissues of 14 patients without tumor. Eleven commercial antibodies were used for a nuclear staining of hTERT expression. With the anti-hTERT antibodies we looked for both satisfactory distribution and intensity of immunohistochemical labeling in the carcinomas and in the squamous epithelia of the tumor centers, of the tumor-free margins and of the control tissues. The hTERT
\end{abstract}

Correspondence to: Dr Eva-Maria Fabricius, Charité Universitätsmedizin, Campus Virchow Hospital, Clinic for Oral and Maxillofacial Surgery, Augustenburger Platz 1, D-13353 Berlin, Germany

E-mail: eva-maria.fabricius@charite.de

Abbreviations: aa, amino acid; Ab, antibody; APAAP, alkaline phosphatase anti-alkaline phosphatase; bp, base pairs; BCC, basal cell carcinoma; EDTA, ethylene diamine tetraacetic acid; ELISA, enzyme linked immuno sorbent assay; HNSCC, head neck squamous cell carcinoma; hTERT, human telomerase reverse transcriptase; IRS, immunoreactive scores; PCR, polymerase chain reaction; RT-PCR, reverse transcriptions-PCR; TBS, tris buffered saline; TRAP, telomeric repeat amplification protocol; TRS, target retrieval solution

Key words: basal cell carcinoma (BCC), tumor margin, telomerase, hTERT, p53, immunohistochemistry, frozen sections, prognosis expression in the BCC was distributed heterogeneously. The score values established by the anti-hTERT antibodies used were variably or significantly increased. In the stroma they tended to be negative, so we disregarded stroma hTERT. Proof of hTERT did not differ uniformly from telomerase activity. We compared the high with the lower median hTERT values in the Kaplan-Meier curve. Patients with lower hTERT scores in the center or tumor margin as shown by some of the antibodies suffered relapse earlier. Finally, we compared the hTERT expression in BCC tissues with the hTERT scores in HNSCC tissues from our previous study. Only one anti-hTERT antibody (our Ab 7) yielded significantly higher scores in BCC than in HNSCC.

\section{Introduction}

In recent years basal cell carcinomas (BCC) have been the most frequent non-melanoma skin tumors (1-10) world-wide and their incidence is increasing each year. Epidemiological data $(5,6,8,9,11-16)$ show clearly that ultraviolet (UV) radiation, particularly UVB, is an essential etiological factor in the carcinogenesis of skin tumors. UV exposure is a chronic oxidative stress (17) that causes DNA damage with specific mutations of suppressor genes such as p53 (14,16,18-22): it is activated along with telomerase (23-27). Molecular changes in the skin are associated with local cell proliferation. BCCs are characterized by a high rate of loco-regional recurrence and secondary tumors. An important cause of this is field cancerization (28) in the area around the BCC (29-32). Studies are in progress to find the best suited molecular or immunohistochemical markers for characterizing tumor-free margin tissue $(8,12,13,24,33-36)$.

Since the development of the TRAP (telomeric repeat amplification protocol) by Kim et al (37) it is possible to demonstrate telomerase activity in many tumors in larger studies. Many investigations have demonstrated telomerase activity in basal cell carcinomas and their tumor margins (2326,38-51). In our BCC-study we looked for a difference in telomerase activity between $\mathrm{BCC}$-free tumor margin tissue of head and neck tumors, the tumor itself and control tissue $(24,26,49)$. Proof of telomerase by PCR provides no information about telomerase expression in the isolated cells, but immunohistochemistry is well suited for the in situ presentation of telomerase positive cells, providing that 
suitable antibodies are available. This prompted us in the present study to subject the same frozen tissues in which we had demonstrated telomerase activity by PCR ELISA to an immunohistochemical investigation to find out specifically which cells express the catalytic protein subunit of telomerase, hTERT (human telomerase reverse transcriptase).

As for the in situ proof of hTERT in frozen sections of squamous cell carcinoma (SCC) tissues in the head-neck region (52), hTERT evidence in cryo sections of BCCs was presented using 11 commercial antibodies to hTERT for appropriate nuclear demonstration of hTERT in BCC tissues.

\section{Patients and methods}

Collection of tissue samples. For all tissues in our study we obtained the consent previously of the patients who were in our clinic for diagnostics and therapy in the period between 1994 and 2004: 50 basal cell carcinoma specimens from 41 patients and 14 extraoral control samples from 14 patients without tumor in that period. Control tissue collected from younger patients was also taken with previous consent from their parents.

The entire frozen section series was examined by a tumor pathologist (G.P. Wildner) with conventional hemalaun-eosin staining to ensure that carcinoma was present in all tumor center tissue specimens and that the tumor margins were all tumor-free.

BCC tissues. We examined tissue from various locations and with various histopathologies from 26 male patients $(63 \%)$ aged $62 \pm 14$ years and 15 female patients (37\%) aged $70 \pm 17$ years. They were classified according to Soyer and Rippey $(53,54)$. All tumor samples originated from non-covered areas of the head or the upper trunk. We examined tissue from 25 tumor centers and 25 tumor-free margins. In the tumor center, carcinoma and squamous epithelium were evaluated; in the tumor margin squamous epithelium as well as stroma were examined. The patient data are summarized in Table I.

Patients without cancer and control tissue specimens. For a more critical evaluation of hTERT expression in carcinoma tissues we examined extraoral control tissue without tumor from different locations in the head-neck region from our clinic in the period from 1994 to 2004: 9 males aged 29 \pm 17 years and 5 females aged $34 \pm 21$ years. In the control tissue sections we evaluated hTERT in squamous epithelium. We examined extraoral tissues from the eye $(1 x)$, nose $(3 x)$, ear $(4 x)$, skin $(2 x)$, lips $(1 x)$ scalp $(2 x)$ and forehead $(1 x)$. The tissues were taken with the patients' consent in the context of therapy in our clinic.

Immunohistochemistry and immunoreactive score values (IRS). We used the frozen sections from basal cell carcinomas in which we had previously demonstrated telomerase activity in PCR ELISA $(24,49)$. As already reported (52), we optimized nuclear hTERT demonstration by working with four commercially available anti-hTERT antibodies, the three polyclonal rabbit antibodies, code PC 563 from Oncogene, EST21-A from Alpha Diagnostics and code 582005 by
Calbiochem and the monoclonal murine antibody clone 44F12 by NovoCastra. We also introduced further antihTERT antibodies. To visualize the outcome we performed the alkaline phosphatase anti-alkaline phosphatase (APAAP, 56) for the current study, as it had proved successful in our earlier immunohistochemical examinations (57-59). The APAAP was more suitable in our study of hTERT evidence than EnVision ${ }^{\mathrm{TM}}$ (DakoCytomation, Denmark) (52). After methanol and acetone fixation, the slides with the frozen sections were pretreated for $30 \mathrm{~min}$ in a steamer $\left(95-99^{\circ} \mathrm{C}\right)$ in TRS buffer (target retrieval solution) S1699 (Dako Cytomation). All anti-hTERT antibodies and all control antibodies used in the study were pretreated in the same way. Pretreatment in the steamer proved the most effective for the nuclear presentation of hTERT in frozen sections.

All incubation steps taken in the immunohistochemical staining process were performed in a humidified chamber. To block non-specific reactions we incubated sections at room temperature for $20 \mathrm{~min}$ with the ready-made X0909 blocking buffer (DakoCytomation). Between each step the sections were rinsed thoroughly three times in TBS buffer, $\mathrm{pH} 7.6$ (Tris buffered saline, concentrated 10x, S3001 DakoCytomation; with $\mathrm{pH}$ of dilution at 7.6).

All antibodies were diluted in S2022 (DakoCytomation, ready to use). We determined the optimal dilution for each antibody in accordance with the product data sheets. Antibodies were incubated for $60 \mathrm{~min}$ at $37^{\circ} \mathrm{C}$ in the drying oven and then for $30 \mathrm{~min}$ at room temperature. Table II lists the eleven anti-hTERT antibodies and the four primary control antibodies. In the case of some antibodies only a limited number of tissues were stained.

The APAAP (56) used to present the antigen antibody reaction was carried out as follows: The two bridge antibodies were incubated at room temperature at 1:40 (diluted in antibody dilution plus $5 \%$ AB serum by Biotest AG, Dreieich, Germany; Cat. 805135). For sections with polyclonal primary antibodies (Table II: Ab 1, Ab 2, Ab 4 to Ab 9 and Ab 13) monoclonal mouse anti-rabbit bridge antibody (DakoCytomation M0737) were applied and for sections with monoclonal antibodies (Table II: Ab 3, Ab 10, Ab 11, Ab 12, $\mathrm{Ab} 14$ and $\mathrm{Ab}$ 15) polyclonal rabbit anti-mouse bridge antibody (DakoCytomation Z0259) were used. Sections were then incubated for $40 \mathrm{~min}$ with the monoclonal APAAP complex (DakoCytomation D0651), diluted 1:100 in antibody dilution plus 5\% inactivated fetal calf serum (FKS, Biochrom AG, Berlin, S0115, Germany). Substrate development lasted approximately 20 min (gauged by visual judgment) with DakoCytomation K0624 substrate plus 2 additional drops of levamisole (K5000 by DakoCytomation) per $3 \mathrm{ml}$ of substrate. The sections were counterstained with hemalaun (DakoCytomation S2020) for 5 min with subsequent blueing for $5 \mathrm{~min}$ in tap water.

The results of immunohistochemistry were interpreted with control antibodies (Table II): Ki-67 (Ab 12) to prove proliferation and for better recognition of basal cell carcinomas in the small frozen sections, and CD45 (Ab 14) for better visualization of lymphocyte mononuclear infiltration. In previous examinations we had only been able to prove a limited correlation between telomerase activity and lymphocyte infiltration in tumor margin tissues $(24,60-63)$. We 
Table I. Characterization of the 41 patients with a basal cell carcinoma.

\begin{tabular}{|c|c|c|c|c|c|}
\hline Pat. code-no. & Sex/age $^{\mathrm{a}}$ (years) & Tumor site & Tissue source & Tumor spead & Histopathology \\
\hline 1 & $\mathrm{M} / 53$ & eye & $\mathrm{TC}$ & $\mathrm{T} 1$ & nodular \\
\hline 2 & $\mathrm{M} / 82$ & eye & $\mathrm{TC}$ & $\mathrm{T} 1$ & nodular \\
\hline 3 & $\mathrm{M} / 51$ & eye & $\mathrm{TM}$ & $\mathrm{T} 1$ & nodular \\
\hline 4 & $\mathrm{M} / 38$ & eye & $\mathrm{TC}$ & $\mathrm{T} 2$ & nodular \\
\hline 5 & $\mathrm{M} / 67$ & eye & $\mathrm{TC}$ & $\mathrm{T} 1$ & nodular-sclerodermiform \\
\hline 6 & $\mathrm{~F} / 86$ & eye & TM & $\mathrm{T} 1$ & sclerodermiform \\
\hline 7 & $\mathrm{~F} / 60$ & lips & TC & $\mathrm{T} 1$ & nodular \\
\hline 8 & $\mathrm{M} / 90$ & lips & $\mathrm{TC}$ & $\mathrm{T} 1$ & nodular-sclerodermiform \\
\hline 9 & $\mathrm{M} / 90$ & lips & $\mathrm{TC}, \mathrm{TM}$ & $\mathrm{T} 1$ & nodular \\
\hline 10 & $\mathrm{~F} / 51$ & lips & $\mathrm{TC}, \mathrm{TM}$ & $\mathrm{T} 1$ & sclerodermiform \\
\hline 11 & $\mathrm{M} / 61$ & lips & $\mathrm{TM}$ & $\mathrm{T} 1$ & nodular \\
\hline 12 & $\mathrm{M} / 54$ & nose & $\mathrm{TC}$ & $\mathrm{T} 1$ & nodular \\
\hline 13 & $\mathrm{M} / 85$ & nose & TC, TM & $\mathrm{T} 1$ & nodular \\
\hline 14 & $\mathrm{~F} / 52$ & nose & TC, TM & $\mathrm{T} 1$ & nodular-sclerodermiform \\
\hline 15 & $\mathrm{~F} / 96$ & nose & TC & $\mathrm{T} 1$ & nodular \\
\hline 16 & $\mathrm{M} / 76$ & nose & TC & $\mathrm{T} 2$ & nodular \\
\hline 17 & $\mathrm{M} / 38$ & nose & $\mathrm{TC}$ & $\mathrm{T} 2$ & nodular \\
\hline 18 & $\mathrm{M} / 58$ & nose & TM & $\mathrm{T} 1$ & sclerodermiform \\
\hline 19 & $\mathrm{~F} / 55$ & nose & TM & $\mathrm{T} 1$ & nodular \\
\hline 20 & $\mathrm{~F} / 86$ & nose & $\mathrm{TM}$ & $\mathrm{T} 1$ & nodular \\
\hline 21 & $\mathrm{M} / 68$ & nose & $\mathrm{TC}, \mathrm{TM}$ & $\mathrm{T} 2$ & nodular \\
\hline 22 & $\mathrm{~F} / 78$ & nose & $\mathrm{TC}$ & $\mathrm{T} 1$ & nodular \\
\hline 23 & $\mathrm{M} / 58$ & nose & $\mathrm{TC}$ & $\mathrm{T} 1$ & nodular \\
\hline 24 & $\mathrm{M} / 63$ & nose & $\mathrm{TM}$ & $\mathrm{T} 2$ & nodular \\
\hline 25 & $\mathrm{~F} / 86$ & nose & $\mathrm{TC}$ & $\mathrm{T} 1$ & nodular-sclerodermiform \\
\hline 26 & $\mathrm{M} / 58$ & nose & TM & $\mathrm{T} 1$ & nodular \\
\hline 27 & $\mathrm{~F} / 80$ & nose & TC, TM & $\mathrm{T} 2$ & nodular \\
\hline 28 & $\mathrm{~F} / 55$ & nose & $\mathrm{TM}$ & $\mathrm{T} 1$ & nodular \\
\hline 29 & $\mathrm{M} / 79$ & nose / shoulder & $\mathrm{TC}, \mathrm{TM}$ & $\mathrm{T} 1$ & nodular-sclerodermiform \\
\hline 30 & $\mathrm{M} / 57$ & ear & $\mathrm{TM}$ & $\mathrm{T} 2$ & superficial \\
\hline 31 & $\mathrm{M} / 45$ & ear & $\mathrm{TM}$ & $\mathrm{T} 1$ & nodular \\
\hline 32 & $\mathrm{~F} / 52$ & ear & $\mathrm{TM}$ & $\mathrm{T} 1$ & sclerodermiform \\
\hline 33 & $\mathrm{M} / 60$ & shoulder / back & $\mathrm{TM}$ & $\mathrm{T} 1$ & nodular-sclerodermiform \\
\hline 34 & $\mathrm{~F} / 52$ & shoulder / back & $\mathrm{TM}$ & $\mathrm{T} 1$ & superficial \\
\hline 35 & $\mathrm{M} / 56$ & scalp & $\mathrm{TM}$ & $\mathrm{T} 2$ & nodular \\
\hline 36 & $\mathrm{~F} / 88$ & scalp & $\mathrm{TC}$ & $\mathrm{T} 1$ & nodular \\
\hline 37 & $\mathrm{~F} / 70$ & forehead & $\mathrm{TC}$ & $\mathrm{T} 1$ & nodular \\
\hline 38 & $\mathrm{M} / 55$ & forehead & $\mathrm{TC}, \mathrm{TM}$ & $\mathrm{T} 1$ & nodular \\
\hline 39 & $\mathrm{M} / 55$ & cheek & $\mathrm{TC}, \mathrm{TM}$ & $\mathrm{T} 1$ & sclerodermiform \\
\hline 40 & $\mathrm{M} / 60$ & cheek & TM & $\mathrm{T} 1$ & superficial \\
\hline 41 & M/61 & cheek & $\mathrm{TC}$ & $\mathrm{T} 2$ & nodular \\
\hline
\end{tabular}

Sex: M, male; F, female; ${ }^{a}$ Age at tissue harvesting; TC, tumor center; TM, tumor margin; T1, maximal tumor spread 20 mm; T2, tumor spread $>20 \mathrm{~mm}$, TNM classification (55).

expanded our investigation and incorporated an anti-nucleolin antibody (Ab 13) to clarify this issue since the monoclonal anti-hTERT antibody (clone 44F12, code NCL-hTERT, Table II, Ab 3) was classified in the paper by Wu et al (64) as an antibody against nucleolin.
In addition to characterize BCC (24) we used a monoclonal antibody against mutated p53 Ab-3 (Ab 15, Table II). To ensure the reliability of our immunohistochemical stainings we ran a parallel assay with a negative control for each staining (negative control sera mouse DAKO code N1698, 
Table II. Overview of primary antibodies used [hTERT sequence in Wu et al (64)].

\begin{tabular}{|c|c|c|c|c|}
\hline Ab-code & Antibodies & Source, code & Characterization & Working dilution \\
\hline $\mathrm{Ab} 1$ & $\begin{array}{l}\text { Polyclonal rabbit } \\
\text { anti-telomerase } \mathrm{Ab}\end{array}$ & $\begin{array}{l}\text { Oncogene (from Calbiochem, } \\
\text { USA) code PC } 563\end{array}$ & $\begin{array}{l}\text { Anti-hTERT (amino acids 348-358 } \\
\text { of human hTERT). IgG-Ab }\end{array}$ & $1: 10$ \\
\hline $\mathrm{Ab} 2$ & $\begin{array}{l}\text { Polyclonal rabbit } \\
\text { anti-EST-2 Ab } \\
\text { (affinity pure) }\end{array}$ & $\begin{array}{l}\text { Alpha Diagnostics } \\
\text { International, USA } \\
\text { code EST21-A }\end{array}$ & $\begin{array}{l}\text { Anti-hTERT against the } 16 \text {-aa peptide } \\
\text { EST21-P, sequence mapping in the } \\
\text { middle of human EST-2 was selected } \\
\text { for antibody production. The peptide } \\
\text { was coupled to KLH, antibody } \\
\text { was generated in rabbit. } \operatorname{IgG}_{1}-\mathrm{Ab}\end{array}$ & $1: 25$ \\
\hline $\mathrm{Ab} 3$ & $\begin{array}{l}\text { Mouse monoclonal } \\
\text { anti-telomerase } \\
\text { (catalytic unit) liquid } \\
\text { Ab (clone 44F12) }\end{array}$ & $\begin{array}{l}\text { NovoCastra, UK } \\
\text { code NCL-L-hTERT }\end{array}$ & $\begin{array}{l}\text { Against procaryotic recombinant fusion } \\
\text { protein corresponding to a } 148 \text { amino } \\
\text { acid truncate (aa } 173-320 \text { ), a region } \\
\text { near the N-terminal. } \operatorname{IgG}_{2 \mathrm{a}}-\kappa-\mathrm{Ab}\end{array}$ & $1: 10$ \\
\hline $\mathrm{Ab} 4$ & $\begin{array}{l}\text { Polyclonal rabbit } \\
\text { anti-telomerase } \mathrm{Ab}\end{array}$ & $\begin{array}{l}\text { Calbiochem, USA } \\
\text { code } 582005\end{array}$ & $\begin{array}{l}\text { Immunogen used was a synthetic } \\
\text { peptide corresponding to an internal } \\
\text { region of the catalytic subunit of } \\
\text { human telomerase reverse transcriptase } \\
\text { (hTERT), recognizes the } \sim 125 \mathrm{kDa} \\
\text { telomerase (TERT) protein. IgG-Ab }\end{array}$ & $1: 250$ \\
\hline $\mathrm{Ab} 5$ & $\begin{array}{l}\text { Polyclonal rabbit } \\
\text { anti-TERT (H-231) } \\
\text { Ab,unconjugated }\end{array}$ & $\begin{array}{l}\text { Santa Cruz Biotechnology, } \\
\text { Inc., USA } \\
\text { code sc- } 7212\end{array}$ & $\begin{array}{l}\text { Against amino acids } 900-1130 \\
\text { mapping at the } \mathrm{C} \text {-terminus of TERT } \\
\text { of human origin. IgG-Ab }\end{array}$ & $1: 10$ \\
\hline $\mathrm{Ab} 6$ & $\begin{array}{l}\text { Polyclonal rabbit } \\
\text { anti-telomerase } \mathrm{Ab}\end{array}$ & $\begin{array}{l}\text { Calbiochem, } \\
\text { code } 582000\end{array}$ & $\begin{array}{l}\text { Immunogen used was a synthetic } \\
\text { peptide corresponding to amino acids } \\
\text { from an internal region of the catalytic } \\
\text { subunit of human telomerase reverse } \\
\text { transcriptase (hTERT), recognizes } \\
\text { the } \sim 125 \mathrm{kDa} \text { telomerase (TERT) } \\
\text { protein. IgG-Ab }\end{array}$ & $1: 250$ \\
\hline $\mathrm{Ab} 7$ & $\begin{array}{l}\text { Polyclonal rabbit } \\
\text { anti-telomerase } \mathrm{Ab}\end{array}$ & $\begin{array}{l}\text { Abcam, USA } \\
\text { code ab177 }\end{array}$ & $\begin{array}{l}\text { Immunogen a peptide from } \\
\text { the mTERT protein component } \\
\text { from telomerase. } \mathrm{IgG}-\mathrm{Ab}\end{array}$ & $1: 250$ \\
\hline $\mathrm{Ab} 8$ & $\begin{array}{l}\text { Polyclonal rabbit } \\
\text { anti-telomerase } \mathrm{Ab} \\
\text { (affinity purified) }\end{array}$ & $\begin{array}{l}\text { Abcam, } \\
\text { code ab23699 }\end{array}$ & $\begin{array}{l}\text { Immunogen a synthetic peptide } \\
\text { conjugated to KLH derived } \\
\text { from within residues } 550-650 \text { of } \\
\text { human telomerase. IgG-Ab }\end{array}$ & $1: 25$ \\
\hline $\mathrm{Ab} 9$ & $\begin{array}{l}\text { Polyclonal rabbit } \\
\text { anti-telomerase } \\
\text { catalytic subunit } \\
\text { (hTERT) } \\
\text { (affinity purified) }\end{array}$ & $\begin{array}{l}\text { Rockland, USA } \\
\text { code } 600-401-252\end{array}$ & $\begin{array}{l}\text { The antibody was prepared from } \\
\text { whole rabbit serum produced by } \\
\text { repeated immunizations with a } \\
\text { synthetic peptide corresponding to a } \\
\text { region near the carboxy terminal end } \\
\text { of hTERT (aa 1104-1123). IgG-Ab }\end{array}$ & $1: 50$ \\
\hline $\mathrm{Ab} 10$ & $\begin{array}{l}\text { Monoclonal mouse } \\
\text { anti-telomerase } \\
\text { reverse } \\
\text { transcriptase } \mathrm{Ab} \\
\text { (clone 2D8) }\end{array}$ & $\begin{array}{l}\text { Novus Biologicals, USA } \\
\text { code NB 100-297 }\end{array}$ & $\begin{array}{l}\text { Immunogen full-length recombinant } \\
\text { hTERT from insect cells. IgM-Ab }\end{array}$ & $1: 50$ \\
\hline
\end{tabular}


Table II. Continued.

\begin{tabular}{|c|c|c|c|c|}
\hline Ab-code & Antibodies & Source, code & Characterization & Working dilution \\
\hline $\mathrm{Ab} 11$ & $\begin{array}{l}\text { Monoclonal mouse } \\
\text { anti-telomerase } \\
\text { reverse } \\
\text { transcriptase } \\
\text { (clone 2C4) } \\
\text { Positive control } \\
\text { antibodies }\end{array}$ & $\begin{array}{l}\text { Novus Biologicals, } \\
\text { code NB 100-317 }\end{array}$ & $\begin{array}{l}\text { Immunogen full-length recombinant } \\
\text { hTERT from insect cells. IgM-Ab }\end{array}$ & $1: 100$ \\
\hline $\mathrm{Ab} 12$ & $\begin{array}{l}\text { Monoclonal mouse } \\
\text { anti-human Ki-67 } \\
\text { antibody } \\
\text { (clone MIB-1) }\end{array}$ & $\begin{array}{l}\text { DAKO, Denmark } \\
\text { code M7240 }\end{array}$ & $\begin{array}{l}\text { Immunogen human recombinant } \\
\text { peptide corresponding to a } 1002 \mathrm{bp} \\
\mathrm{Ki}-67 \mathrm{cDNA} \text { fragment. } \\
\mathrm{IgG}_{1}-\mathrm{K}-\mathrm{Ab}\end{array}$ & $1: 100$ \\
\hline $\mathrm{Ab} 13$ & $\begin{array}{l}\text { Polyclonal rabbit } \\
\text { antibody } \\
\text { against nucleolin }\end{array}$ & $\begin{array}{l}\text { Abcam } \\
\text { code ab22758 }\end{array}$ & $\begin{array}{l}\text { Immunogen synthetic peptide } \\
\text { conjugated to KLH derived within } \\
\text { residues 1-100 from human nucleolin. } \\
\text { IgG-Ab }\end{array}$ & $1: 400$ \\
\hline $\mathrm{Ab} 14$ & $\begin{array}{l}\text { Monoclonal mouse } \\
\text { Ab CD45RB } \\
\text { (clone PD7/26) } \\
\text { against leucocyte } \\
\text { common antigen }\end{array}$ & $\begin{array}{l}\text { DAKO } \\
\text { code M0833 }\end{array}$ & $\begin{array}{l}\text { Reacts with B cell, T cell subsets, } \\
\text { monocytes, macrophages and } \\
\text { weakly with granulocytes. } \\
\mathrm{IgG}_{1}-\mathrm{K}-\mathrm{Ab}\end{array}$ & $1: 100$ \\
\hline $\mathrm{Ab} 15$ & $\begin{array}{l}\text { Monoclonal } \\
\text { antibody against } \\
\text { mutated p53 Ab-3 } \\
\text { (clone PAb240) }\end{array}$ & $\begin{array}{l}\text { Oncogene } \\
\text { code OP } 29\end{array}$ & $\begin{array}{l}\text { A recombinant protein consisting of } \\
\text { amino acids } 14-389 \text { of } \mathrm{p} 53 \text { fused to } \\
\text { ß-galactosidase within amino acids } \\
\text { 213-217. } \mathrm{IgG}_{1}-\mathrm{Ab}\end{array}$ & $1: 20$ \\
\hline
\end{tabular}

aa, amino acid; Ab, antibody; KLH, keyhole limpet hemocyanin.

negative control sera rabbit DAKO code N1699; ready for use). These contol sera were constantly negative.

The score values for hTERT, Ki-67, nucleolin and p53 refer exclusively to nuclear and/or nucleolar stainings in the carcinomas or squamous epithelia. The expression of CD45 was evaluated in the whole tissues. In analogy to our previous immunohistochemical studies with other antibodies (57-59) we used the immunohistochemical evaluation by Remmele et al (65-66) and two independent observers calculated the score values. Evaluation of the sections was performed three times and was based on estimated values for staining intensity (SI: 0, no staining; $1+$, weak; $2+$, moderate; $3+$, strong and 4+, very strong staining) and percentage of positive staining in tissue sections (PP: 0, no positive cells; 1, 1-25\%; 2, 26-50\%; $3,51-75 \%$ and $4,76-100 \%$ positive cells). The immunohistochemical score value (IRS) was then calculated by multiplication of SI and PP. The evaluation was performed with a 40-fold objective.

Determining telomerase activity in the same frozen tissue samples. As described above $(24,26,49,62-63)$, we used the test kits TeloTAGGG Telomerase PCR ELISA (Roche Diagnostics - Applied Science, Mannheim, Germany, catalog no. 11854666910) and TeloTAGGG Telomerase PCR ELISA $^{\text {Plus }}$ (Roche Diagnostics - Applied Science, catalog no. 12013789001) for demonstration of telomerase activity. The frozen tissues were lysed, the lysate adjusted with the addition of 0.5 and $5 \mu \mathrm{g}$ protein or, if necessary, amounts under $0.5 \mu \mathrm{g}$ with PCR. We conducted the examination following suppliers' instructions. It was necessary to use the TeloTAGGG Telomerase PCR ELISA ${ }^{\text {Plus }}$ kit because its internal standards make it possible to check for any false negative findings caused by inhibition of the PCR. With a subsequent ELISA it was then possible to detect telomerase activity in MOD.

In earlier studies $(24,62)$ we had worked out an evaluation scheme: we classified the telomerase activity, measured in mOD, into five groups: 0 , negative, TA $0-150 \mathrm{mOD} ; 1+$, TA 150-450 mOD; 2+, TA 450-750 mOD; 3+, TA 750-1050 mOD; 4+, TA above 1050 mOD.

Statistical evaluation. For statistical evaluation, SPSS 15.0 for Windows, Version 15.0.1 (22 November 2006) was available (67). We used the script of the Charité Institute for Biomathematics and Biometry for Human Medicine (68) and Sachs (69). Apart from the descriptive statistics, we compared median values using the Mann-Whitney U-test or, 


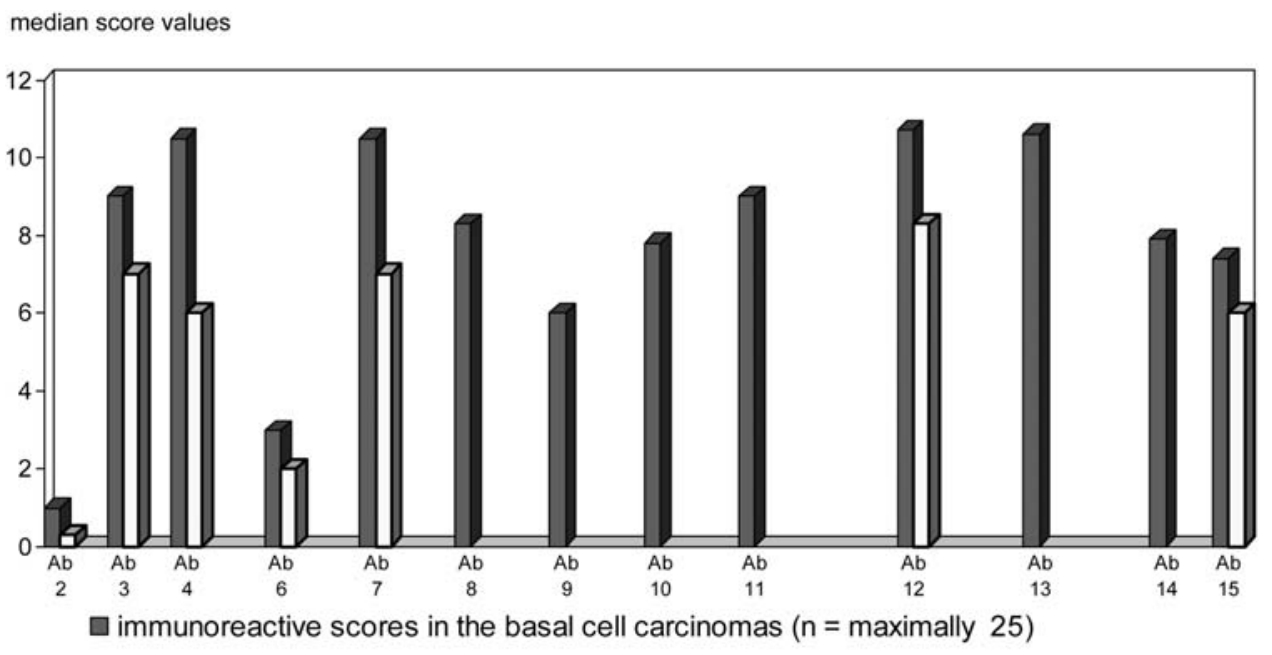

$\square$ immunoreactive scores in the squamous epithelia $(n=$ maximally 22$)$

$\mathrm{Ab}$, antibody; anti-hTERT antibodies Ab 2 to 4, Ab 6 to 11, control antibodies Ab 12, Ki-67; Ab 13, anti-nucleolin; $\mathrm{Ab} 14, \mathrm{CD} 45$ and Ab 15, anti mutated p53 (Table II).

Figure 1. Median values of immunohistochemical scores (IRS) for hTERT expression in the basal cell carcinomas and squamous epithelium of the same tissue samples.

if distribution was normal, we compared mean values using the t-test. Test results for difference with $p<0.05$ were rated as statistically significant.

To determine the relation between the telomerase activity and the immunohistochemical score values we applied the two-sided Spearman's rank correlation coefficient (Spearman's rho). If the result was above the tabulated value of 0.05 there is a correlation between the measurements examined. We tested for their interdependence. We applied the Fisher's exact test considering the small number of tissue specimens. Given the relatively low number of patients, we reduced all values into two groups for the statistical comparison of incidence (immunoreactive score values and telomerase activity) in the Fisher's exact tests. We divided all values into group 0 and group 1: for group 0 values $<$ median value and for group 1 values $\geq$ median value. The median value was chosen as the cut-off value because the score values were not normally distributed.

For testing the prognostic statement made by these values in the Kaplan-Meier curves we used the patient outcome documentation in our hospital. We recorded the number of months between tissue excision and relapse or secondary basal cell carcinoma. We applied two hTERT groups to the Kaplan-Meier curves. The difference of the curves compared was significant when log-rank test proved $\mathrm{p}<0.05$.

\section{Results}

Expression of hTERT in basal cell carcinoma tissue samples. The data of patients with a basal cell carcinoma, all of which were collected after patients' consent, are summarized in Table I. We investigated hTERT expression in these tissues with the eleven anti-hTERT antibodies (Table II). With Ab 1 (polyclonal anti-telomerase code PC 563) and Ab 5 (polyclonal anti-TERT H-231, code sc-7212) the immunohistochemical hTERT scores were lower (or negative) than with the other nine antibodies. We therefore applied these antibodies only for some sections and did not document these results in detail.

Table III summarizes the telomerase activity and immunoreactive hTERT score values found in the basal cell carcinoma tissues. With Ab 2 and Ab 6 the hTERT scores were particularly low (Fig. 1), with Ab 6 they were higher than with Ab $2(p=0.091)$. The order of succession of the median hTERT scores in BCC tumor center tissues was Ab 4=Ab 7 , Ab 3=Ab 11, Ab 8, Ab 10, Ab 9, Ab 6 and Ab 2.

Fig. 1 shows the median score values for hTERT expression and for the control antibodies (Tables III and IV) in basal cell carcinomas and in squamous epithelia of the same tissues. The figure reveals that the polyclonal antibody anti-EST2 (code EST21-A, Ab 2, Table II) and the antitelomerase $\mathrm{Ab}$ code 582000, Ab 6 (Table II) were the antibodies least suited for demonstrating hTERT in frozen tissues. In the comparison of the higher hTERT scores in BCC in tumor center tissues rendered by $\mathrm{Ab} 3, \mathrm{Ab} 4$ and $\mathrm{Ab} 7$ to $\mathrm{Ab} 11$ (U- or t-test: p between 0.204 and 0.942) only between Ab 7 and $\mathrm{Ab} 9$ was there a difference which even approximated significance $(\mathrm{p}=0.088)$.

Table IV summarizes the immunoreactive score values in the BCC-free squamous epithelium in tumor center tissue samples. Immunohistochemistry was done only with antihTERT Ab 2 to Ab 4 and Ab 6 to Ab 7 (Table II). The U-test rendered score values for anti-hTERT antibodies Ab 2 to $\mathrm{Ab} 4$ and $\mathrm{Ab} 6$ to $\mathrm{Ab} 7$ which were higher in tumor center tissues than in squamous epithelium of the same tissue sample, with Ab 4 significantly higher $(\mathrm{p}=0.015)$.

We also investigated the expression in basal cell carcinomas of the four control antibodies, of anti-Ki-67 (Ab 12), anti-nucleolin (Ab 13), CD45 (Ab 14) and anti-mutated p53 (Ab 15, Table II) and summarize the scores with the control antibodies in Tables III and IV.

Contrary to the significant difference between the expression of Ki-67 and CD45 ( $\mathrm{p}=0.007)$ neither in the statistical comparison (U- or t-test) of the immunoreactive 
Table III. Telomerase activity and expression of hTERT, Ki-67, nucleolin (Ab 13) and p53 (Ab 15) in basal cell carcinomas (patient data in Table I) and CD45 in the whole tissues: immunoreactive score values (IRS).

\begin{tabular}{|c|c|c|c|c|c|c|c|c|c|c|c|c|c|c|}
\hline No. & TA & $\begin{array}{l}\text { IRS } \\
\mathrm{Ab} 2\end{array}$ & $\begin{array}{l}\text { IRS } \\
\mathrm{Ab} 3\end{array}$ & $\begin{array}{l}\text { IRS } \\
\mathrm{Ab} 4\end{array}$ & $\begin{array}{c}\text { IRS } \\
\text { Ab } 6\end{array}$ & $\begin{array}{l}\text { IRS } \\
\text { Ab } 7\end{array}$ & $\begin{array}{l}\text { IRS } \\
\text { Ab } 8\end{array}$ & $\begin{array}{l}\text { IRS } \\
\text { Ab } 9\end{array}$ & $\begin{array}{c}\text { IRS } \\
\text { Ab } 10\end{array}$ & $\begin{array}{c}\text { IRS } \\
\text { Ab } 11\end{array}$ & $\begin{array}{c}\text { IRS } \\
\text { Ki-67 }\end{array}$ & $\begin{array}{c}\text { IRS } \\
\mathrm{Ab} 13\end{array}$ & $\begin{array}{c}\text { IRS } \\
\text { CD45 }\end{array}$ & $\begin{array}{l}\text { IRS } \\
\text { p53 }\end{array}$ \\
\hline 1 & $2+$ & 2 & 5.25 & 12 & 6 & 1 & 9 & 10.5 & 2.5 & 1.25 & 12 & 12 & 10 & 8 \\
\hline 2 & $4+$ & 3 & 9 & 14 & 2 & 2 & 10.5 & 7 & 10.5 & 12 & 12 & 12 & 6 & 4 \\
\hline 4 & $1+$ & 0 & 12 & 10.5 & 0 & 4 & 14 & - & - & - & 12 & - & 12 & 12 \\
\hline 5 & $3+$ & 0.8 & 6 & 6 & 6 & 5 & 5 & 7.5 & 6 & 6 & 10 & - & 9 & 4 \\
\hline 7 & $1+$ & 7 & 12 & 10.5 & 1 & 7 & 10 & 10.5 & 4 & - & 12 & - & 10 & 12 \\
\hline 8 & $4+$ & 4 & 10 & 14 & 1 & 8 & 12 & - & - & - & 12 & - & 2 & 5 \\
\hline 9 & $1+$ & 1.5 & 14 & 7.5 & 4 & 9 & 12 & 10 & 7 & 7 & 12 & 8 & 0.2 & 9 \\
\hline 10 & $1+$ & 1 & 7.5 & 12 & 4.5 & 10 & 10 & - & 4 & - & 12 & - & 0.5 & 12 \\
\hline 12 & $1+$ & 1.5 & 12 & 8 & 5 & 12 & 6 & 0 & 6 & 7 & 8 & 8 & 1 & 4 \\
\hline 13 & $2+$ & 6.8 & 12 & 12 & 6.25 & 13 & 10.5 & 12.25 & 12 & 12 & 12 & 12 & 4 & 12 \\
\hline 14 & $2+$ & 7.5 & 16 & 10.5 & 3 & 14 & 12 & - & 10.5 & 12 & 8 & 8 & 6 & 8 \\
\hline 15 & $4+$ & 0.8 & 8.75 & 3 & 1.5 & 15 & 8.75 & - & - & - & 8 & - & 12 & 8 \\
\hline 16 & $2+$ & 5 & 9 & 0 & 7.5 & 16 & 12.25 & 5.4 & 6 & 7 & 8 & 8 & 12 & 7 \\
\hline 17 & $2+$ & 0.5 & 0 & 0.5 & 0.5 & 17 & 6 & - & - & - & 12 & - & 12 & 9 \\
\hline 21 & $3+$ & 1.6 & 12 & 16 & 9.9 & 21 & 6 & 7.5 & 10.5 & 12 & 10 & 12 & 12 & 5.25 \\
\hline 22 & $4+$ & 8.75 & 9 & 12 & 2 & 22 & 10.5 & 6 & 7 & 12 & 10 & 7 & 12 & 8 \\
\hline 23 & $1+$ & 0 & 6 & 7.5 & 7.5 & 23 & 12 & - & - & - & 12 & 12 & 12 & 8 \\
\hline 25 & $3+$ & 0 & 12 & 3 & 1 & 25 & 12.3 & - & - & 8 & 12 & 12 & 12 & 12 \\
\hline 27 & $2+$ & 0 & 7 & 12 & 3 & 27 & 10.5 & 12 & - & - & 12 & - & 8 & 10.5 \\
\hline 29 & $3+$ & 12 & 8 & 12 & 1.6 & 29 & 10.5 & 9 & 0.5 & 7.5 & 12 & 9 & 8 & 6 \\
\hline 36 & - & 0 & 12.25 & 10.5 & 1 & 36 & 7 & - & - & - & 12 & - & 2 & 2.25 \\
\hline 37 & $3+$ & 0.5 & 7 & 16 & 4 & 37 & 0.8 & 4 & 16 & 8.75 & 12 & 12 & 10.5 & 12 \\
\hline 38 & $2+$ & 0 & 0 & 0 & 0 & 38 & 2.5 & - & - & - & 2.5 & - & 4 & 0 \\
\hline 39 & $2+$ & 3 & 12 & 10 & 3 & 39 & 14 & - & - & - & 16 & - & 12 & 1 \\
\hline 41 & $2+$ & 0 & 5.25 & 16 & 0.4 & 41 & 14 & - & - & - & 12 & - & 7.5 & 6 \\
\hline
\end{tabular}

TA, telomerase activity; 0, negative, TA 0-150 mOD; 1+, TA 150-450 mOD; 2+, TA 450-750 mOD; 3+, TA 750-1050 mOD; 4+, TA above 1050 mOD; IRS, immunoreactive scores; Ab, antibody (Table II); -, not examined.

score values between $\mathrm{Ki}-67(\mathrm{Ab} 12)$ and anti-nucleolin $(\mathrm{Ab}$ 13) (t-test: $\mathrm{p}=0.261$ ) nor between $\mathrm{CD} 45$ (Ab 14) and antinucleolin in BCC were there significant differences (U-test: $\mathrm{p}=0.140$ ). Notably, the Ki-67 (Ab 12) scores are significantly higher in the basal cell carcinoma than in squamous epithelium of the tumor center tissues: $\mathrm{p}=0.032$ (U-test). Finally, the score values of mutated p53 were not significantly higher in the tumor center tissues than in squamous epithelium of the tumor center tissues ( $\mathrm{t}$-test: $\mathrm{p}=0.213$ ). In BCC tissues the difference between the score values by Ab 3 (code NCL-LhTERT) and Ab 13 (anti-nucleolin antibody, Table II) were not significant $(\mathrm{n}=8: \mathrm{p}=0.259)$. According to $\mathrm{Wu}$ et al (64) NCL-L-hTERT has the characteristics of an anti-nucleolin antibody.

Using the Fisher's exact test we explored whether hTERT expression in BCC corresponded with telomerase activity in the same tissues (Table III). Once again we formed two groups (see 'Patients and methods'). The test revealed a statistical correlation with telomerase activity: between $\mathrm{p}=1.000$ (hTERT expression shown by Ab 2, Ab 4, Ab 9 and $\mathrm{Ab} 3$ ) and $\mathrm{p}=0.101$ (expression revealed by $\mathrm{Ab} 6$, Table II).
These results did not correspond to the examination by Spearman's rank correlation coefficient with the exact hTERT scores and telomerase activity in mOD. As demonstrated in some examples this might be due to the heterogeneous distribution of data: Fig. 2.

Using the Fisher's exact test we also addressed the question of whether there is a relationship between the telomerase activity in the whole tumor center tissues and the immunoreactive hTERT scores in the squamous epithelia of the tumor center tissues (Table IV). None of the comparisons were significant (p-value range 0.192-1.000), so that a correlation between telomerase activity and hTERT score values can be assumed. The Spearman's rank correlation coefficients showed no correlation between the telomerase activity in $\mathrm{mOD}$ and the exact hTERT scores.

There was a statistical correlation between telomerase activity and expression of the control antibodies. P-values ranged between 0.101 (Ab 6), 0.193 (Ki-67), 0.303 (Ab 8), 0.534 (Ab 11), 0.592 (Ab 10), 0.679 (Ab 7) and $1.000(\mathrm{Ab} \mathrm{2,}$ $\mathrm{Ab} 3, \mathrm{Ab} 4$, anti-nucleolin $\mathrm{Ab}=\mathrm{Ab} 13$ and $\mathrm{CD} 45=\mathrm{Ab} 14)$. The controversial NCL-L-hTERT antibody referred to by $\mathrm{Wu}$ 
Table IV. Telomerase activity and expression of hTERT, Ki-67 (Ab 12) and p53 (Table II) in squamous epithelia from tumor center tissue samples (immunoreactive score values, IRS).

\begin{tabular}{|c|c|c|c|c|c|c|c|c|}
\hline No. & TA & $\begin{array}{c}\text { IRS } \\
\mathrm{Ab} 2\end{array}$ & $\begin{array}{l}\text { IRS } \\
\text { Ab } 3\end{array}$ & $\begin{array}{l}\text { IRS } \\
\mathrm{Ab} 4\end{array}$ & $\begin{array}{c}\text { IRS } \\
\mathrm{Ab} 6\end{array}$ & $\begin{array}{l}\text { IRS } \\
\mathrm{Ab} 7\end{array}$ & $\begin{array}{c}\text { IRS } \\
\text { Ab } 12\end{array}$ & $\begin{array}{l}\text { IRS } \\
\text { p53 }\end{array}$ \\
\hline 1 & $2+$ & 1.6 & 5.25 & 8.75 & 5 & 0.6 & 4.5 & 1.75 \\
\hline 2 & $4+$ & 4 & 1.5 & 4 & 1 & 4 & 4 & 1 \\
\hline 4 & $1+$ & 0 & 8 & 9 & 0 & 8.75 & 12 & 9 \\
\hline 5 & $3+$ & 0 & 3 & 6 & 2 & 1.5 & 3 & 1 \\
\hline 7 & $1+$ & 7 & 9 & 2 & 1 & 8 & 12 & 12 \\
\hline 8 & $4+$ & - & - & - & - & - & - & - \\
\hline 9 & $1+$ & - & - & - & - & - & - & - \\
\hline 10 & $1+$ & 0 & 7.5 & 12 & 3 & - & 12 & 8 \\
\hline 12 & $1+$ & 1.5 & 12 & 0 & 2 & 4 & 8 & 2 \\
\hline 13 & $2+$ & 0.8 & 4 & 12 & 6 & 12 & 8 & 4 \\
\hline 14 & $2+$ & 3 & 9 & 7 & 2 & 9 & 2 & 2.5 \\
\hline 15 & $4+$ & 2 & 7 & 0 & 1.5 & 10.5 & 8 & 8 \\
\hline 16 & $2+$ & 0 & 9 & 0 & 4 & 12 & 8 & 6 \\
\hline 17 & $2+$ & - & 0.45 & - & - & 9 & - & - \\
\hline 21 & $3+$ & 3 & 7 & 12 & 6 & 2 & 10 & 4 \\
\hline 22 & $4+$ & 0.3 & 6 & 6 & 1 & 7 & 10 & 6 \\
\hline 23 & $1+$ & 1 & 12 & 7.5 & 7.5 & 10.5 & 12 & 8 \\
\hline 25 & $3+$ & 0 & 12 & 3 & 1 & 10.5 & 12 & 12 \\
\hline 27 & $2+$ & 4 & 0 & 0 & 3 & 4 & 8 & 4 \\
\hline 29 & $3+$ & 0 & 6 & 1.6 & 1.6 & 4 & 3 & 12 \\
\hline 36 & - & - & - & - & - & - & - & - \\
\hline 37 & $3+$ & 1 & 7 & 10.5 & 4 & 0.5 & 12 & 12 \\
\hline 38 & $2+$ & 0 & 0 & 0 & 0 & 1 & 2.5 & 2 \\
\hline 39 & $2+$ & 0 & 8.75 & 6 & 2.25 & 9 & 12 & 5 \\
\hline 41 & $2+$ & 0 & 8.75 & 0.7 & 0.4 & 0.8 & 12 & 6 \\
\hline
\end{tabular}

TA, telomerase activity; 0, negative, TA 0-150 mOD; 1+, TA 150-450 mOD; 2+, TA 450-750 mOD; 3+, TA 750-1050 mOD; 4+, TA above $1050 \mathrm{mOD}$; Ab, (Table II); -, not examined or no squamous epithelium present in section.

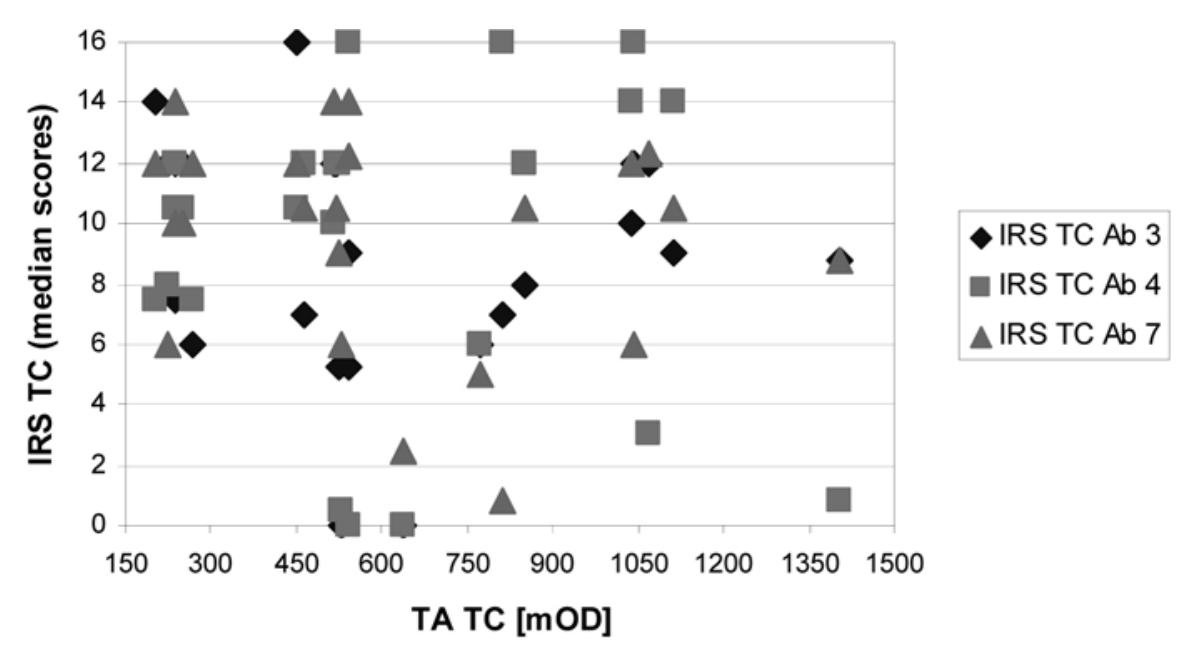

$\mathrm{Ab}=$ antibody (anti-hTERT Ab 3, Ab 4, Ab 7 Table II); IRS, immunoreactive scores;

$\mathrm{TA}$, telomerase activity; TC, tumor center.

Figure 2. Scatterplot between telomerase activity in the tumor center tissues [mOD] and the immunohistochemical score values (IRS) for hTERT-expression with $\mathrm{Ab} 3, \mathrm{Ab} 4$ and $\mathrm{Ab} 7$ in the same basal cell carcinoma tissues. 
Table V. Telomerase activity, expression of hTERT, Ki-67 and p53 in squamous epithelia of the tumor-free tumor margin of basal cell carcinomas (patient data in Table I) and of CD45 in the whole tissues of tumor margin tissues.

\begin{tabular}{|c|c|c|c|c|c|c|c|c|c|}
\hline No. & TA & $\begin{array}{c}\text { IRS } \\
\text { Ab } 2\end{array}$ & $\begin{array}{c}\text { IRS } \\
\text { Ab } 3\end{array}$ & $\begin{array}{c}\text { IRS } \\
\mathrm{Ab} 4\end{array}$ & $\begin{array}{l}\text { IRS } \\
\text { Ab } 6\end{array}$ & $\begin{array}{c}\text { IRS } \\
\mathrm{Ab} 7\end{array}$ & $\begin{array}{c}\text { IRS } \\
\text { Ki-67 }\end{array}$ & $\begin{array}{c}\text { IRS } \\
\text { CD45 }\end{array}$ & $\begin{array}{l}\text { IRS } \\
\text { p53 }\end{array}$ \\
\hline 3 & 0 & 6.25 & 7.5 & 3.75 & 1 & 10.5 & 12 & 9 & 12 \\
\hline 6 & $1+$ & - & - & - & - & - & - & 8 & - \\
\hline 9 & $2+$ & 6 & 1.25 & 4 & - & - & 12 & 3.2 & 0.8 \\
\hline 10 & 0 & 0 & 4 & 8 & 10.5 & 5 & 10.5 & 10.5 & 9 \\
\hline 11 & $3+$ & - & - & - & - & - & - & 8 & - \\
\hline 13 & 0 & 0 & 12 & 0.8 & 0.8 & 6 & 8 & 12 & 8 \\
\hline 14 & $1+$ & 0.8 & 12 & 4 & 0 & 5 & 8 & 4 & 1.5 \\
\hline 18 & 0 & 1 & 3 & 7 & 1.5 & 6 & 3 & 4 & 6 \\
\hline 19 & 0 & - & - & - & - & - & - & 3 & - \\
\hline 20 & 0 & - & - & - & - & - & - & 1 & - \\
\hline 21 & $1+$ & 12 & 12 & 7 & 4 & 8.75 & 8 & 6 & 12 \\
\hline 24 & $1+$ & - & - & - & - & - & - & 10.5 & - \\
\hline 26 & $1+$ & 12 & 8 & 2 & 1 & 12 & 8 & 8 & 12 \\
\hline 27 & $3+$ & - & - & - & - & - & - & 2 & - \\
\hline 28 & 0 & - & - & - & - & - & - & 6 & - \\
\hline 29 & 0 & 0 & 0 & 9 & 4 & 3 & 4 & 8 & 1.2 \\
\hline 30 & 0 & - & - & - & - & - & - & 0.8 & - \\
\hline 31 & 0 & 0 & 8 & 3.75 & 2.25 & 0.4 & 8 & 9 & 0 \\
\hline 32 & 0 & 8 & 2.5 & 9 & 0 & 3.75 & 8 & 6 & 3 \\
\hline 33 & 0 & 6 & 9 & 5 & 6 & 0.3 & 8 & 3 & 3 \\
\hline 34 & 0 & 0 & 3.2 & 6 & 0 & 3 & 2 & 4 & 2 \\
\hline 35 & 0 & 0.8 & 4 & 9 & 4 & 8.75 & 4 & 6 & 1.8 \\
\hline 38 & $2+$ & 1 & 1.5 & 1 & 0.16 & 0 & 3 & 5 & 10 \\
\hline 39 & 0 & 1 & 8.75 & 0 & 0 & 2 & 8 & 2 & 1.5 \\
\hline 40 & 0 & 1 & 6 & 7 & 12.25 & 10.5 & 8 & 12 & 6 \\
\hline
\end{tabular}

TA, telomerase activity; 0, negative, TA 0-150 mOD; 1+, TA 150-450 mOD; 2+, TA 450-750 mOD, 3+, TA 750-1050 mOD; IRS, immunoreactive scores; Ab, antibody (Table II); -, no squamous epithelium in section.

et al (64) yielded no significance $(\mathrm{p}=0.559)$ compared to the anti-nucleolin scores.

Expression of hTERT in tumor-free resection margin tissue of the BCC. Table V summarizes the immunoreactive hTERT scores for BCC-free tumor margin tissue containing squamous epithelium. Table I shows patient data, Fig. 3 the median values of the immunoreactive scores.

The same two polyclonal antibodies anti-EST2 (Ab 2) and anti-telomerase code 582000 (Ab 6, Table II) which had shown the lowest hTERT scores in all tumor center tissues of our study (Fig. 1), also showed the lowest hTERT scores in the squamous epithelia of BCC-free tumor margin tissue (Fig. 3). With all antibodies, expression in squamous epithelium in the tumor center was usually higher than or equal to that in the tumor margin tissue (U-test: p-value range 0.184-0.977). All squamous epithelial hTERT score values from the tumor margin were lower than those in tumor center tissues and significantly lower with $\mathrm{Ab} 3, \mathrm{Ab} 4$ and $\mathrm{Ab} 7$ (U-test $\mathrm{p}=0.019, \mathrm{p}=0.003$, respectively, $\mathrm{p}<0.001$ ).
The highest score values were presented by the squamous epithelium from the tumor tissue sample and the tumor margin with Ab 3 (NCL-hTERT), but the score values with $\mathrm{Ab} 4$ and $\mathrm{Ab} 7$ were not significantly lower (in the tumor center tissues: p between 0.186 and 0.737 , in the tumor margin tissues: p-value range 0.479-0.886).

The hTERT scores of squamous epithelium in the center of basal cell carcinomas and of the BCC-free tumor margin did not differ significantly from the scores for Ki-67 $(\mathrm{p}=0.235)$ and for $\mathrm{p} 53(\mathrm{p}=0.461)$ in the U-test, while Ki-67 scores presented no significant difference in the tumor center tissue ( $\mathrm{p}=0.089$ and $\mathrm{p}=0.095)$.

Using the Chi-square test (or Fisher's exact test) we tested for a correlation between hTERT expression in the squamous epithelium of BCC-free tumor margin and telomerase activity in the tumor margin (p-value range 1.000-0.153) and for a correlation between the CD45 score values in the same tissue and hTERT expression (p-value range 0.622-0.118). We found a connection with all parameters. This, however, was not confirmed by Spearman's rank correlation coefficients 


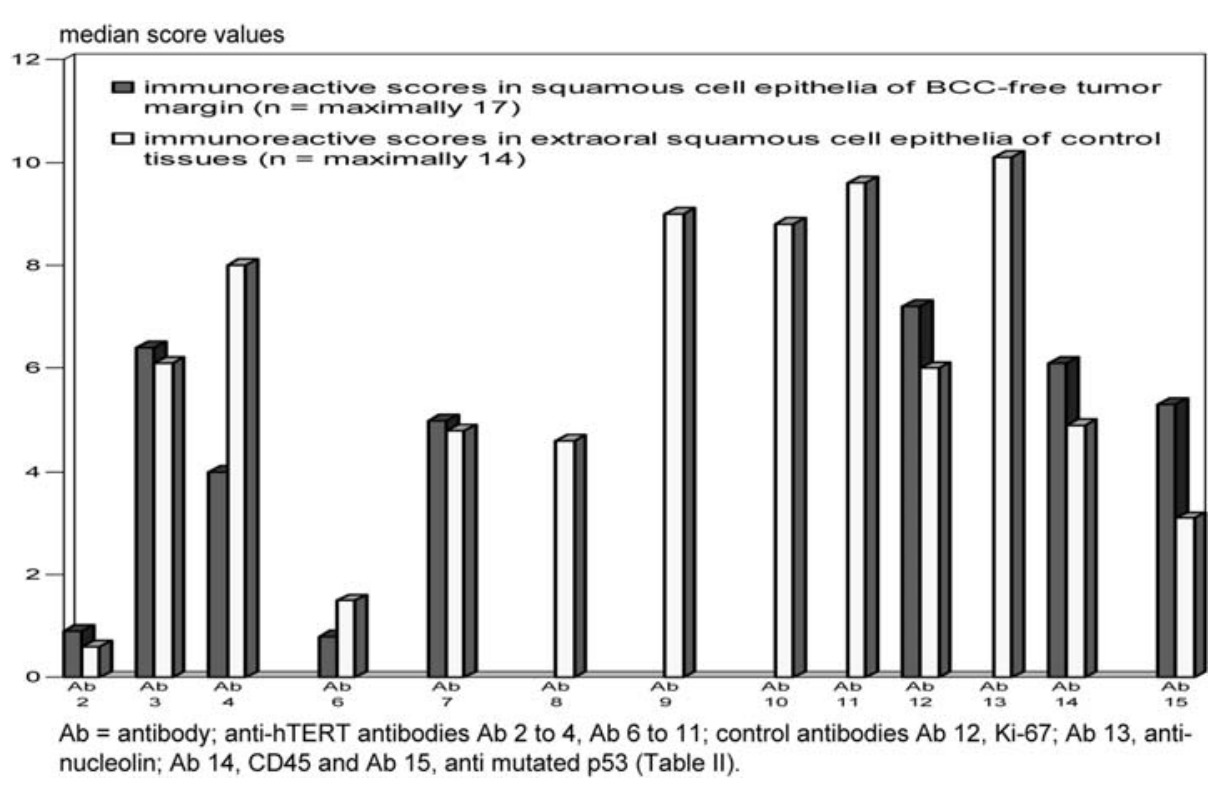

Figure 3. Median values of immunohistochemical scores (IRS) for hTERT expression in squamous epithelium of tumor-free margins and in control tissues from patients without tumor.

which rendered no correlation between telomerase activity in $\mathrm{mOD}$ and the exact scores values.

Expression of hTERT in extraoral control tissues. Resulting immunoreactive hTERT score values for 14 extraoral squamous epithelia are listed in Table VI; median values are illustrated in Fig. 3.

Fig. 3 also illustrates the low sensitivity of antibodies Ab 2 and Ab 6 (Table II), disqualifying them for detection of hTERT expression in squamous epithelia from control tissues. The immunoreactive scores of control tissue samples were very heterogeneously distributed in the squamous epithelium itself and varied with the individual antibody. We compared the hTERT-scores in the U-test (or the t-test). Statistically the scores with $\mathrm{Ab} 2$ were significantly lower than those with $\mathrm{Ab} 3, \mathrm{Ab} 4, \mathrm{Ab} 9$ to $\mathrm{Ab} 11$ ( $\mathrm{p}<0.001-\mathrm{p}=0.04)$; with Ab 6 significantly lower than with $\mathrm{Ab} 3$ ( $\mathrm{p}<0.001)$, and with $\mathrm{Ab} 7$ significantly lower than with $\mathrm{Ab} 10(\mathrm{p}=0.034)$. The scores with Ab 6 were higher but not significantly higher than with $\mathrm{Ab} 2(\mathrm{p}=0.368)$. The highest hTERT scores in extraoral control tissues were with $\mathrm{Ab} 11, \mathrm{Ab} 9, \mathrm{Ab} 10$ and $\mathrm{Ab} 4, \mathrm{Ab} 3, \mathrm{Ab} 7, \mathrm{Ab} 8, \mathrm{Ab} 6$ and $\mathrm{Ab} 2$ (note that this successive order is the inverse of that registered in $\mathrm{BCC}$ tissues). Most of the score values between the $\mathrm{Ab} 3$ to $\mathrm{Ab} 4$ and $\mathrm{Ab} 7$ to $\mathrm{Ab} 11$ in squamous epithelia of control tissues were not significant (U- or t-test: p-value range 0.1590.966). However, score values with Ab 7 were significantly higher than with Ab $10(\mathrm{p}=0.034)$, and nearly reached significance with $\mathrm{Ab} 11(\mathrm{p}=0.054)$ and $\mathrm{Ab} 9(\mathrm{p}=0.082)$.

The scores of Ki-67, CD45 and p53 are significantly lower in the squamous epithelia of the extraoral control tissues than in the BCC tissues (U-test: $\mathrm{p}<0.001$, $\mathrm{p}=0.034$ and $\mathrm{p}=0.001$ ).

In the Fisher's exact test there was a connection between telomerase activity in the control tissues and the hTERTscore values as well as between telomerase activity in the control tissues and the scores for control antibodies (all p- values were $>0.05$ ). However, proof of exact score values with telomerase activity in mOD using Spearman's rank coefficients showed no correlations.

Localizing hTERT with selected anti-hTERT antibodies. The distribution of hTERT-positive cells was usually very heterogeneous in the individual basal cell carcinomas irrespective of the antibody used (Table III). In some basal cell carcinomas, however, distribution of positive cells was restricted to the peripheral area of the carcinoma. Where squamous epithelium in tissues from tumor patients or in control tissue was still normal, the hTERT-positive cells were limited to one or two basal layers. However, in hyperplastic or more or less severely dysplastic squamous epithelium, suprabasal hTERT was also evident or was spread over the entire squamous epithelium.

Fig. 4 shows some of the immunohistochemical images collected in these studies comparing the patterns of expression as indicated by the individual anti-hTERT antibodies after pretreatment of the frozen sections in the steamer and visualization by APAAP (56).

Prognostic significance of immunohistochemical proof of hTERT protein in BCC tissues. In order to determine the prognostic significance of hTERT expression we drew Kaplan-Meier curves as described under 'Patients and methods' for each antibody in the carcinoma tissue, in the squamous epithelium of tumor center and tumor margin tissue (Tables III and IV). Data were obtained from the patient documentation in our clinic. Most of the KaplanMeier curves rendered no significant correlation between increased hTERT expression and poor prognosis. Only patients with higher hTERT scores (higher than the median value) in the tumor center (Fig. 5A) and tumor margin tissues (Fig. 5B) as demonstrated with Ab 4 displayed a longer period without recurrence: The mean time period before relapse for those patients from whom tumor center tissues were examined was $13 \pm 2$ months (IRS $<$ median) to $51 \pm 5$ 
A
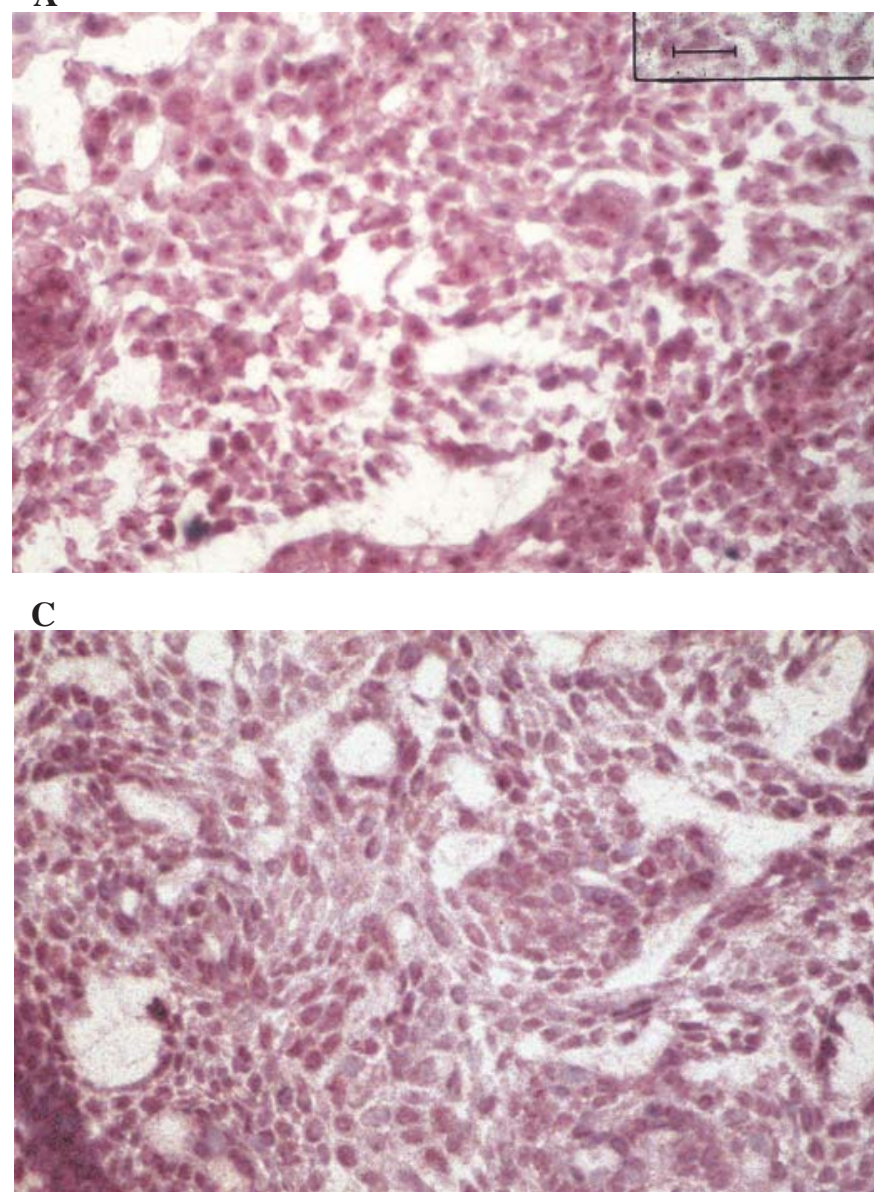

$\mathbf{E}$

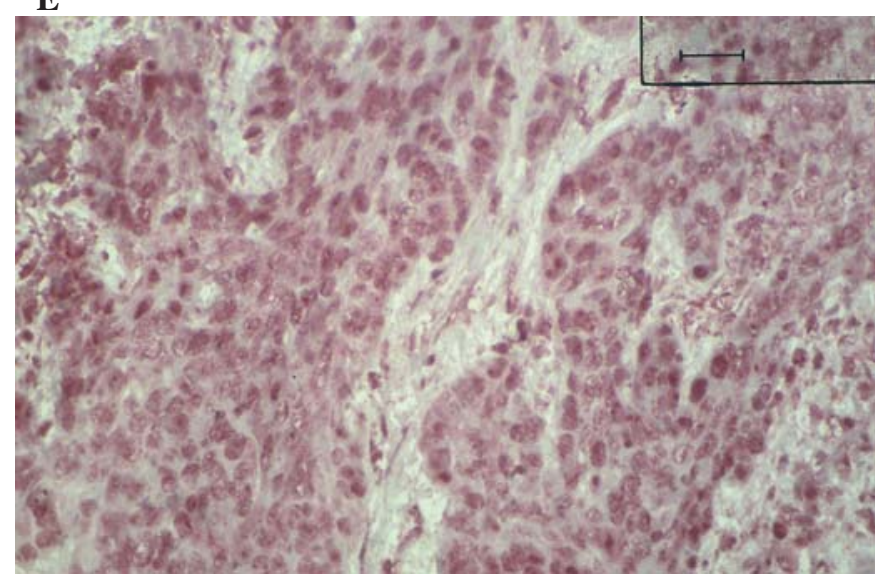

B

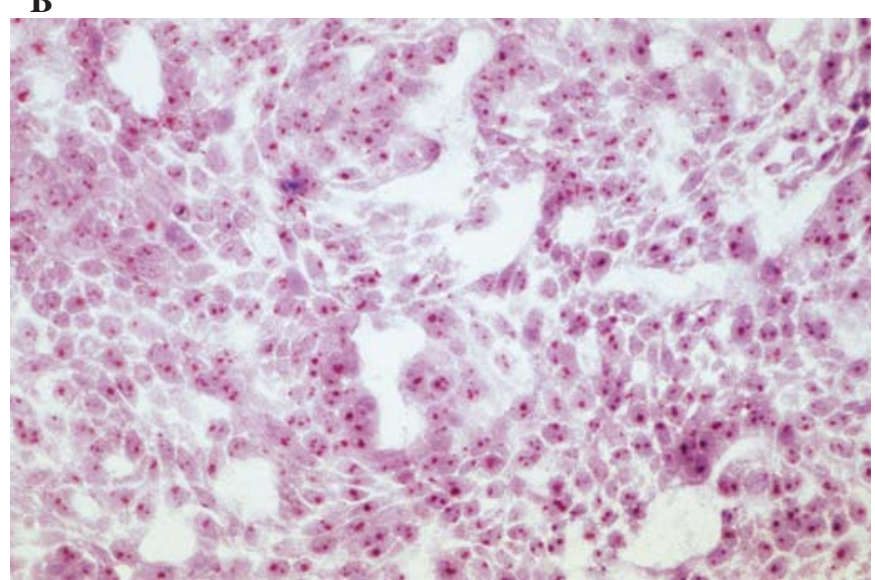

D

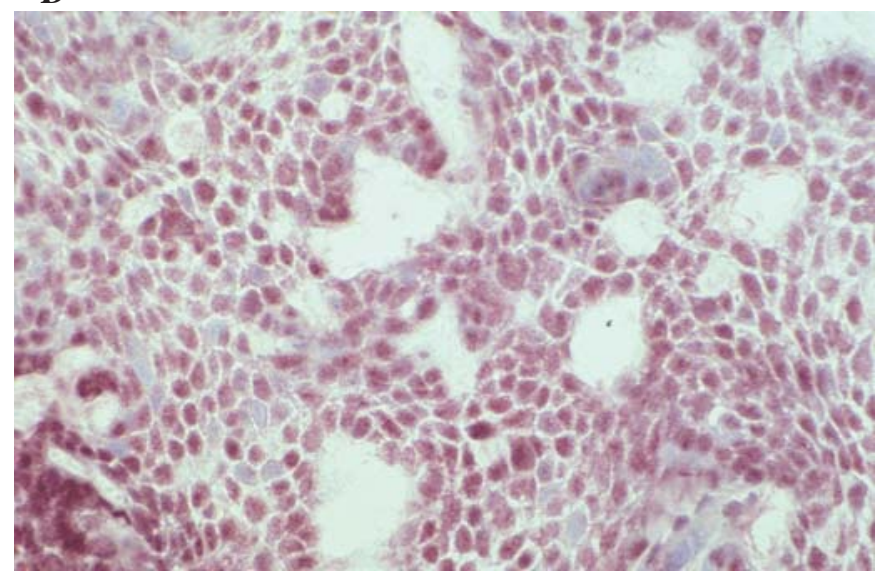

$\mathbf{F}$

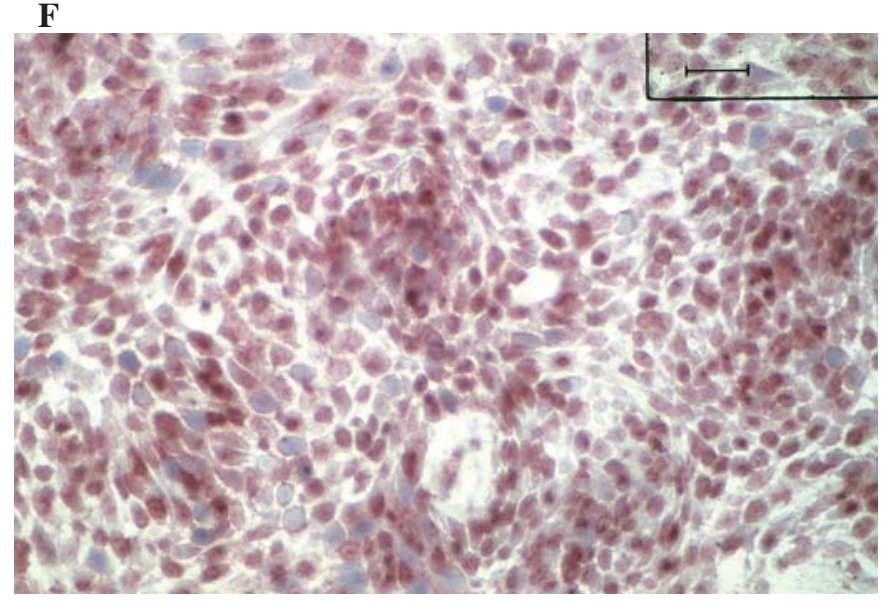

Figure 4. Typical immunohistochemical results of the nodular basal cell carcinoma tissues: (A) Ab 13 (anti-nucleolin, code ab22758); (B) Ab 3 (anti-hTERT NCL-hTERT), (C) Ab 4 (anti-hTERT code 582005), (D) Ab 7 (anti-hTERT code ab177), (E) Ab 10 (anti-hTERT code NB 100-297) and (F) Ab 11 (antihTERT code NB 100-317), Table II; bars, $20 \mu \mathrm{m}$.

months (IRS $\geq$ median): Log-rank test $\mathrm{p}=0.008$. For patients from whom tumor margin tissues were examined it was $25 \pm 10$ months (IRS < median) to $82 \pm 25$ months $($ IRS $\geq$ median): $\log$-rank test $\mathrm{p}=0.056$.

\section{Discussion}

After Kim et al (37) developed the TRAP (telomeric repeat amplification protocol) it became possible to demonstrate telomerase activity in larger studies of various tumors. Since then many researchers have applied this protocol for proof of telomerase activation in basal cell carcinomas $(23,24,26,38$ $41,45,47,48,50)$. Up to now only a few studies with in situ localization of hTERT in BCCs have been published: immunohistochemical studies by Park et al (25), Brasnac et al (70) and Perrem et al (71), an in situ hybridization study by Guttman-Yassky et al (72) and a fluorescence in situ hybridization study by Perrem et al (71). Immunohistochemical investigations on cryo sections are missing altogether.

In the present study we applied immunohistochemistry with commercial antibodies for the in situ demonstration of telomerase activation in frozen sections from basal cell 

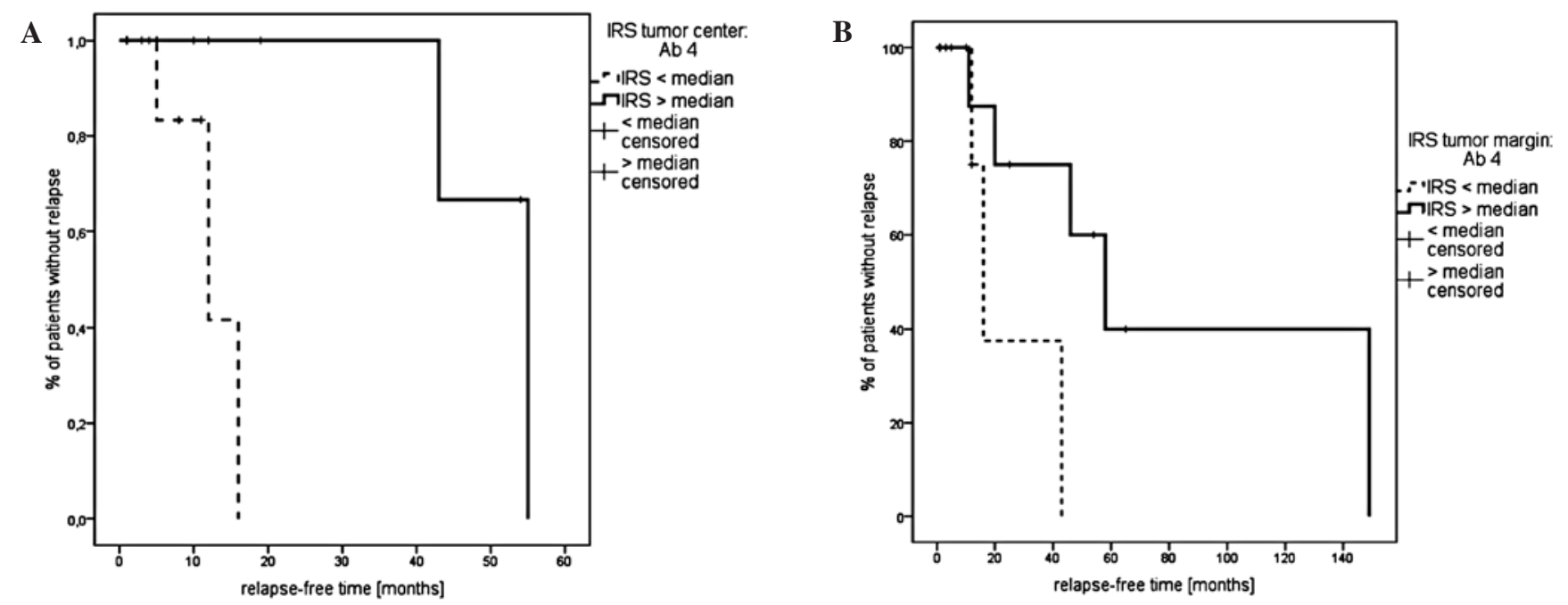

Figure 5. Outcome in patients with a basal cell carcinoma (Table I) and hTERT score values with the polyclonal antibody Ab 4 (code 582005 ) in the tumor center and tumor-free margin tissues: Kaplan-Meier curves for tumor center tissues: log-rank test $p=0.008$; the mean time period until relapse in 15 patients with hTERT score value $\geq$ median value in carcinoma was $51 \pm 5$ months, in 10 patients with score value < median value $13 \pm 2$ months; Kaplan-Meier curves for tumor margin tissues: log-rank test $\mathrm{p}=0.056$; the mean time period until relapse in 13 patients with $h$ TERT score value $\geq$ median value was $82 \pm 25$ months, in 4 patients with score value $<$ median value it was $25 \pm 10$ months.

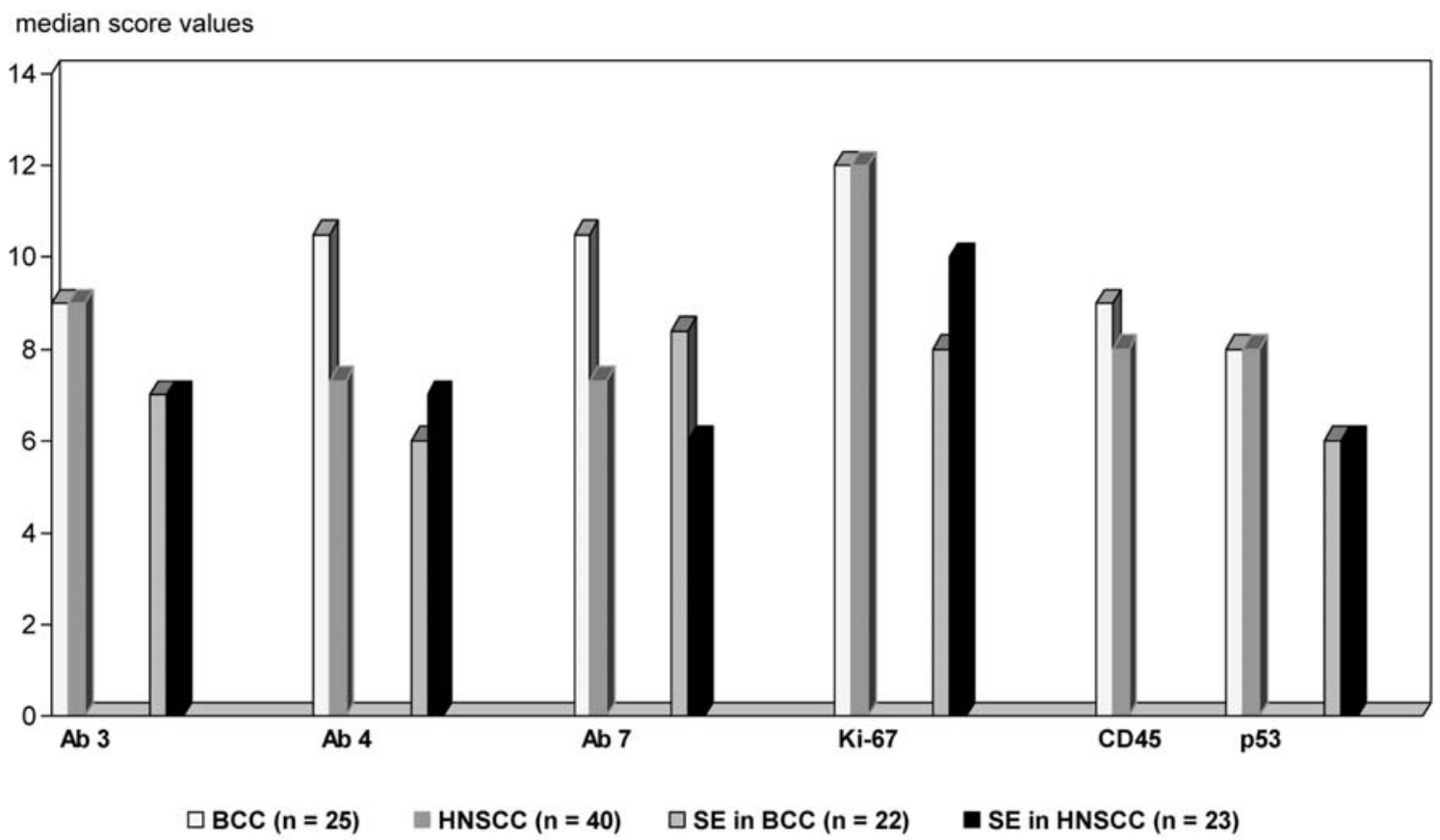

$\mathrm{Ab}$, antibody (Table II); BCC, basal cell carcinoma; HNSCC, head neck squamous cell carcinoma; SE, squamous epithelia.

Figure 6. Comparison of median score values (IRS) in the basal cell carcinomas with score values of the squamous cell carcinomas (52) and with the squamous epithelia in the same tissues.

carcinoma of the head and neck (Table I) and to compare them with extraoral control tissues from patients without tumor. In previous studies with these same carcinoma tissues and BCC-free tumor margin tissues we had proved telomerase activity by PCR ELISA $(24,26,49)$. In this study we wanted to clarify in the same frozen tissues which cells were responsible for the telomerase activity in the tumor margin and in tissues from patients without tumor. We were obliged to use commercial antibodies (Table II).
Methodical procedure and assessment of nuclear demonstration of hTERT on frozen sections from basal cell carcinomas: As already reported (52) we optimized the immunohistochemical nuclear hTERT proof in the basal cell carcinoma and tumor margin tissues with antibodies $\mathrm{Ab} 1$ $\mathrm{Ab} 4$ (Table II) and applied the same method of pretreatment and detection for further anti-hTERT antibodies $\mathrm{Ab} 5$ to $\mathrm{Ab} 11$ and also for the control antibodies (Ab 12 to Ab 15, Table II). We used the same immunohistochemical method, the same 
Table VI. Telomerase activity and expression of hTERT, Ki-67 (Ab 12), nucleolin (Ab 13) and CD45 (Ab 14) in extraoral squamous epithelia of 14 control tissues (IRS).

\begin{tabular}{|c|c|c|c|c|c|c|c|c|c|c|c|c|c|c|}
\hline Control-No. & TA & $\begin{array}{c}\text { IRS } \\
\mathrm{Ab} 2\end{array}$ & $\begin{array}{c}\text { IRS } \\
\mathrm{Ab} 3\end{array}$ & $\begin{array}{c}\text { IRS } \\
\mathrm{Ab} 4\end{array}$ & $\begin{array}{c}\text { IRS } \\
\mathrm{Ab} 6\end{array}$ & $\begin{array}{c}\text { IRS } \\
\text { Ab } 7\end{array}$ & $\begin{array}{c}\text { IRS } \\
\text { Ab } 8\end{array}$ & $\begin{array}{c}\text { IRS } \\
\mathrm{Ab} 9\end{array}$ & $\begin{array}{c}\text { IRS } \\
\mathrm{Ab} 10\end{array}$ & $\begin{array}{c}\text { IRS } \\
\text { Ab } 11\end{array}$ & $\begin{array}{c}\text { IRS } \\
\mathrm{Ab} 12\end{array}$ & $\begin{array}{c}\text { IRS } \\
\text { Ab } 13\end{array}$ & $\begin{array}{c}\text { IRS } \\
\text { Ab } 14\end{array}$ & $\begin{array}{l}\text { IRS } \\
\text { p53 }\end{array}$ \\
\hline Co 1 & 0 & 2 & 9 & 2 & 2 & 1 & 0 & 4 & 5 & - & 8 & 8 & 6 & 8 \\
\hline Co 2 & 0 & 1 & 1 & 12 & 5 & 0 & - & - & - & - & 1 & - & 3 & 0 \\
\hline Co 3 & 0 & 4 & 8 & 12 & 9 & 6 & - & - & - & - & 8 & - & 8 & 2 \\
\hline Co 4 & 0 & - & 0 & - & - & 0 & - & - & - & - & 8 & - & 0 & - \\
\hline Co 5 & 0 & 0 & 6 & 1 & 1 & 8 & 5 & 10 & 9 & 12 & 8 & 10 & 9 & 3 \\
\hline Co 6 & 0 & 0 & 6 & 6 & 2 & 0 & - & - & - & - & 8 & - & 2 & 1 \\
\hline Co 7 & $1+^{\mathrm{a}}$ & 4 & 0 & 12 & 2 & 0 & - & - & - & - & 4 & - & 8 & - \\
\hline Co 8 & 0 & 2 & 4 & 8 & 0 & 5 & - & - & - & - & 4 & 12 & 0 & 4 \\
\hline Co 9 & 0 & 0 & 8 & 6 & 0 & 9 & 11 & 12 & 12 & 9 & 4 & 9 & 8 & 3 \\
\hline Co 10 & 0 & 5 & 12 & 14 & 5 & 12 & 12 & 8 & 12 & 10 & 8 & 14 & 12 & 8 \\
\hline Co 11 & 0 & 0 & 2 & 10 & 2 & 8 & 0 & 16 & 14 & 11 & 8 & - & 5 & - \\
\hline Co 12 & 0 & 0 & 12 & 8 & 0 & 7 & 4 & 1 & 8 & 0 & 2 & 8 & 0 & 0 \\
\hline Co 13 & 0 & 1 & 6 & 7 & 15 & 5 & - & - & 2 & - & 8 & - & 1 & 2 \\
\hline Co 14 & 0 & 0 & 8 & 1 & 0 & 0 & - & - & - & 11 & - & - & 8 & 4 \\
\hline
\end{tabular}

Co, control-No.; TA, telomerase activity; 0, negative, TA 0-150 mOD; 1+, TA 150-450 mOD; Ab, antibody: Table II; IRS, immunoreactive scores; -, not examined or no squamous epithelium in section; ${ }^{\mathrm{T} T A} 187 \mathrm{mOD}$; tissue from nose/nostril.

pretreatments of the frozen slides and the same anti-hTERT antibodies as when we investigated squamous cell carcinoma tissues, Fabricius et al (52).

Conforming to Yan et al (73) no unambiguous nuclear staining was produced with the polyclonal antibody code PC563 by Oncogene/Calbiochem, an antibody against the hTERT amino acid sequence 348-358 (our Ab 1). We abandoned this antibody. With the other three antibodies, the two polyclonal antibodies code EST21-A (Ab 2) and code 582005 (Ab 4) and the monoclonal NCL-L-hTERT (clone 44F12, Ab 3) we worked out the best immunohistological localization of hTERT in the nuclei of the frozen sections. In paraffinembedded tissues or cells Hiyama et al (74), Poremba et al (75-77), Yan et al (73) and Park et al (25) obtained successful nuclear demonstration for hTERT. To achieve nuclear staining in frozen sections, methanol-acetone fixation followed by pretreatment in a steamer in a slightly acidic buffer proved the most suitable method. In paraffin sections Taylor et al (78) applied various antibodies, either without pretreating the sections or after pretreatment in the microwave, autoclave and steamer. Steamers have been used only rarely for frozen sections (79) and up to now not at all for anti-hTERT antibodies. Without pretreatment in the steamer only a few isolated cells presented nuclear staining with all hTERT antibodies used by us and staining was predominantly cytoplasmic or negative. Notably, pretreatment of the frozen sections was not crucial for our control antibodies Ab 12-Ab 15 (Table II).

For the assessment of the semiquantitative immunoreactive hTERT scores $(65,66)$ we included only nuclear antibody marking (Table III to VI). According to Yang et al (80) nucleolar hTERT is associated with telomerase function. We agree with Poremba et al (77) who regarded cytoplasmic staining as non-specific and recorded it as negative.
Proof of hTERT in basal cell carcinomas of the head and neck. The data of patients with BCC are summarized in Table I. We demonstrated hTERT in varying levels in the carcinomatous and in carcinoma-free tumor margin tissue (Tables III-V and Figs. 1-3, 4A-F). In these tissues, the score values with the antibodies EST21-A (Ab 2, Table II) and code 582000 (Ab 6) were the lowest. This result is in accordance with our earlier examination of tissues from squamous cell carcinomas (52). The other antibodies, Ab 3, Ab 4 and Ab 7$\mathrm{Ab} 11$, showed clear nuclear (or nucleolar) marking of carcinoma cells and squamous epithelial cells.

To date only one immunohistochemical study by Park et al (25) is available in which the antibody code 582005 (Ab 4, Table II) was used for hTERT demonstration in paraffin slides from various skin tumors. The authors achieved only cytoplasmic staining, which they demonstrated in $8 / 10$ basal cell carcinomas. The same cytoplasmic staining was described by the authors in squamous cell carcinomas of the skin. Wu et al (41), Boldrini et al (48) and Saleh et al (50) used RT-PCR to test for hTERT in basal cell carcinomas and demonstrated significant hTERT expression in 10/11 (41), 5/37 (48) and 9/12 (50) of the BCCs examined. Wu et al (41) and Boldrini et al (48) used RT-PCR and proved a significant correlation between hTERT expression and telomerase activity and the hTERT expression demonstrated by Saleh et al (50) with the same method was higher in nodal tumors and tumor margins than in superficial BCCs. With in situ hybridization GuttmanYassky et al (72) detected in 2/2 BCC tissues nuclear and cytoplasmic hTERT and Ogoshi et al (81) in 14/15 BCC tissues.

Saleh et al (50) demonstrated significantly lower hTERT in the tumor margin than in the respective BCC, again using real-time PCR. In our study, telomerase activity as demon- 
strated in tumor center tissue was also distinctly, but not significantly higher than in tumor margin tissue $(\mathrm{p}=0.095)$. It corresponded to the decreased hTERT score values of the tumor margin tissues (Tables III-V and Figs. 1 and 2). On the other hand, lymphocytic infiltrates detected in the tumor margin tissues (CD45 IRS scores Tables III and V) were only slightly higher than in tumor center tissues $(\mathrm{p}=0.838)$.

We correlated proof of hTERT in BCC tumor and tumor margin tissues with recurrences in Kaplan-Meier curves. Two Kaplan-Meier curves, one with higher and the other with lower hTERT expression ('Patients and methods'), diverged with significance or approximate significance, despite the ambiguity associated with the presence of many censored cases, when the code 582005 antibody (Ab 4, Table II) was used: $\log$-rank test $\mathrm{p}=0.008$ (tumor center) and $\mathrm{p}=0.056$ (tumor margin), Fig. 5A and B. Altogether, the period without relapse was significantly longer when hTERT expression was higher. These results are contrary to our hTERT results in tissues from squamous cell carcinoma (52).

Comparison of hTERT results in basal cell carcinomas and squamous cell carcinoma of the head and neck. In the earlier study (26) we compared telomerase activity in BCC tissues $(26 / 30=87 \%)$ and in extraoral squamous cell carcinoma tissues $(9 / 12=75 \%)$ from the same region. Our results conformed with those of a review article by Dhaene et al (42): Telomerase activity was detected in $81 \%$ of BCC tissues (21/26) and in $50 \%$ extraoral SCC tissues (9/18). This deviated from the results of Boldrini et al (48), who found high telomerase levels only in $35 \%$ of BCC tissues (7/20) and $75 \%$ of SCC tissues (9/12). In comparison with this hTERT study with basal cell carcinoma tissues and our earlier hTERT study with both oral and extraoral squamous cell carcinoma tissues (52) telomerase activity in the BCCs with the median value of 534 mOD was significantly lower than in the HNSCC tissues with the median value of $999 \mathrm{mOD}(\mathrm{p}=0.012)$ and about significantly lower in the BCC tumor margin tissues with median value of $65 \mathrm{mOD}$ than in the HNSCC tissues with median value of $331 \mathrm{mOD}$ (U-test $\mathrm{p}=0.076$ ).

The aggressive growth for HNSCCs was reflected only by the higher telomerase activity in HNSCC tissues and not by the hTERT score values (52). From the score data in the immunohistochemical hTERT study with squamous cell carcinoma tissues (52) and in this study with BCC tissues it is clear that particular antibodies are more suited for hTERT proof on SCCs and BCCs, respectively. Contrary to these results, the scores with $\mathrm{Ab} 7$ (code ab177) were significantly higher in the BCC tumor center tissues than in HNSCCs (U-test $\mathrm{p}=0.023$ ). Despite the identical hTERT median score value with $\mathrm{Ab} 4$ (code 582005), there were no significantly higher score values in BCC than in $\operatorname{HNSCC}(\mathrm{p}=0.206)$ : Fig. 6.

Contrary to our hTERT results, Boldrini et al (48) with RT-PCR and Park et al (25) with immunohistochemistry using our Ab 4 (code 582005, Table II) found the portion of positive hTERT tissues to be significantly larger in extraoral SCC tissues [9/12 (75\%), respectively, 10/10 (100\%)] than in BCCs [5/37 (14\%), respectively, 7/10 (70\%)]. As opposed to this and in agreement with our immunohistochemical results, Ogoshi et al (81) analysed the in situ hybridization in BCC and extraoral SCC tissues and found hTERT expression in $7 / 8$ SCCs $(88 \%)$ and in $14 / 15$ BCCs $(93 \%)$. Wu et al (41) and $\mathrm{Hu}$ et al (47) observed by RT-PCR a difference in hTERT expression between extraoral SCCs [4/5 (80\%), respectively, 6/8 (75\%) positive] and BCCs [10/11 (91\%), respectively, 4/4 (100\%) positive].

The hTERT results of Kaplan-Meier curves with BCC tissues are doubtful due to the many censored cases (Fig. 5A and B), as opposed to different Kaplan-Meier curves of hTERT results in HNSCC tissues (52). The high hTERT scores of HNSCC tissues correspond with shorter periods without relapse, but not significantly.

Immunohistochemical proof of hTERT in extraoral control tissues. In this study we compared the hTERT scores of BCC tissues only (Tables III and V, Figs. 1-3) with hTERT scores of 14 extraoral control tissues with squamous epithelia (Table VI and Fig. 3) from 14 patients without tumor. Telomerase activity was significantly lower in the control tissues than in BCC center tissues $(\mathrm{p}<0.001)$; it was not significantly lower than in BCC margin tissues $(\mathrm{p}=0.372)$. The squamous epithelium of the control tissues was normal only in part, having been harvested from inflamed tissue or from tissue which was hyperplastic or to varying degrees dysplastic. The hTERT expression in squamous epithelia of control tissues was localized in the basal to parabasal layers, and over the entire epithelium of dysplastic squamous epithelium as well as in squamous epithelia from BCC tissues.

Hiyama et al (74), on the other hand, were able to give immunohistochemical evidence in paraffin sections of hTERT expression in a series of normal cells using the antiEST2 antibody (in our study $\mathrm{Ab}$ 2): in basal keratinocytes of the skin, in basal cells of the endometrium and in epithelial cells from the mamma. Using the monoclonal NCL-hTERT (our Ab 3), according to $\mathrm{Wu}$ et al (64) an anti-nucleolin antibody, Luzar et al (82) found the lowest hTERT expression in normal larynx epithelium from control persons (mean hTERT index 0.17) in comparison to increasing expression in hyperplastic tissue (mean hTERT index 0.44), in basal hyperplasia (mean hTERT index 0.54) and atypical hyperplasia (mean hTERT index 0.91). Volpi et al (83) reported nuclear, nucleolar and cytoplasmic staining of hTERT with a monoclonal antibody Tel 366-10 in normal tissue from skin (among other tissues). With immunohistochemical methods Park et al (25) revealed hTERT expression with the polyclonal antibody by Calbiochem (code 582005, in our study Ab 4, Table II) in 6/10 actinic keratoses. Hu et al (47) were unable to detect hTERT in 5 tissues from normal skin by RT-PCR and, likewise, Ogoshi et al (81) showed low levels or no hTERT with in situ hybridization in 7 protected skin tissues. They did, however, find hTERT expression in all 8 sun-exposed skin tissues.

Which hTERT-positive cells are responsible for telomerase activity in the carcinoma-free resection margins or in the extraoral control tissue and which antibodies show the best immunohistochemical staining in BCC tissues? We detected telomerase activity by PCR ELISA in $9 / 25$ (36\%, Table V) in the tumor margin and in the extraoral control tissues from patients without tumor in $1 / 14$ (7\%, Table VI). Taylor et al 
(38) identified telomerase activity in $67 \%$ of BCC tumor margin tissues examined.

We posed the question of whether the presence of telomerase activation was conditioned by lymphocytic infiltration in the tumor margin or in control tissues and whether there was a higher telomerase expression, indicating field cancerization, in the region surrounding the tumor (28-31). Telomerase activity was identified in activated lymphocytes (60,84-86) and in an attendant lymphocytic infiltration $(87,88)$ described in BCC tumor margin $(38,87)$. In earlier studies we detected a lymphocytic infiltration by histopathology in 12 of $27=44 \%$ (24) and in 13 of $25=52 \%$ (49) tumor margin tissues and in $2 / 14=14 \%$ (49) extraoral control tissues. In this study we applied a monoclonal CD45 antibody (Ab 14, Table II) to evaluate lymphocytic-monocytic infiltrates in tumor margin and control tissues: Tables $\mathrm{V}$ and VI. Statistical comparison revealed a significant variation between the CD45 scores and the extremely low hTERT score values with antibody Ab 2 (Table II) in the tumor margin $(p=0.002)$ and with both antibodies Ab 2 and Ab 6 (Table II) in control tissues ( $\mathrm{p}=0.016$ and $\mathrm{p}=0.043$ ). We also demonstrated isolated hTERT marked cells in the stroma of these tissues.

In an earlier study (49) using histopathological methods we detected field cancerization surrounding the BCC (28-31) after UV radiation with the solar elastosis in 15 of 27 (58\%) tumor margin tissues. The tumor margins were histopathologically BCC-free. In squamous epithelial cells of tumor margins hTERT was expressed distributed in the basal as well as in the suprabasal layer. hTERT expression was highest with the antibodies (in successive order of the median values) $\mathrm{Ab} 4=\mathrm{Ab} 7, \mathrm{Ab} 3$ (Table $\mathrm{V}$ and Fig. 3). In the exact Fisher's test we registered a correlation between hTERT scores and telomerase activation. Ab 4 (code 582005) and Ab 7 (code ab177) were appropriate for sensitive hTERT detection of field cancerization in BCC-free resection margin tissues.

The controversial NCL-hTERT antibody (64), Ab 3 of our study, was also suitable for hTERT detection in frozen sections both in tumor margin and in tumor center tissues. This antibody has been applied by many authors in recent years to demonstrate hTERT in many tumors. Wu et al (64) summarize the most important work done up to 2006 but criticize the use of the NCL-L-hTERT for immunohistochemical demonstration of hTERT. From their investigations of the antibody they concluded that the antibody NCLhTERT targets to nucleolin, rather than hTERT. In our immunoabsorption study with squamous cell carcinoma (52) we tested the anti-hTERT antibody specificity of our antihTERT antibodies $\mathrm{Ab} 3$ to $\mathrm{Ab} 4, \mathrm{Ab} 7$ to $\mathrm{Ab} 11$ and of the anti-nucleolin antibody Ab 13 (Table II) with two hTERT peptides and with a nucleolin peptide (52). The results showed that Ab 3 (NCL-L-hTERT antibody) was not absorbed any more with the nucleolin peptide than were the other anti-hTERT antibodies. In agreement with other researchers $(27,70,71,88-97)$ and despite the objection raised by $\mathrm{Wu}$ et al (64) the Ab 3 proved suitable for hTERT detection. Mitsuishi et al (98) not only confirmed the consideration of Wu et al (64), but also found excellent correlation between nucleolin expression and telomerase activity levels in Bowens's disease and in normal sun- exposed skin. In the immunohistochemical study of Ridley et al (99) hTERT expression in ependymomas with Ab 3 showed very strong correlation with the outcome in pediatric intracranial ependymomas (95). Furthermore, Khurts et al (100) revealed experimentally that nucleolin interacts with telomerase and changes its subcellular localization. In this process it can bind with hTERT, with significant consequences for its own nucleolar localization $(94,100)$. Lam et al (89) proved with an immunohistochemical study in paraffin sections of colorectal carcinomas and the NCL-L-hTERT antibody that telomerase and nucleolin interact with one another and display the same intracellular distribution. Lam et al concluded that despite the criticism of Wu et al (64) telomerase activity can also be demonstrated with this antibody NCL-hTERT.

We did not apply anti-hTERT antibodies Ab 8 (code ab23699), Ab 9 (code 600-401-252), Ab 10 (code NB 100297) and Ab 11 (code NB 100-317, Table II) to tumor margin tissues. But in frozen sections they showed intense nuclear and/or nucleolar marking in basal cell carcinoma (Table III and Fig. 4A-F) and in squamous epithelium of the tumor center (Table III and Fig. 1). The polyclonal antibodies code EST21-A (Ab 2) and code 582000 (Ab 6, Table II) displayed the weakest nuclear staining in frozen sections of our examinations (Tables III-VI, Figs. 1 and 3). With the Ab 2 Hiyama et al (74,101-104) achieved strong nuclear hTERT staining on paraffin-embedded cells and biopsies. Miyazu et al (103) also demonstrated pronounced hTERT expression on paraffin sections from lung tumors and normal lung squamous tissue. The EST21-A antibody attained significant demonstration of hTERT in 23 patients with histopathologically normal epithelium: patients with higher hTERT expression in epithelial tissue developed lung carcinomas. With the polyclonal antibody code 582000 from Calbiochem (Ab 6, Table II) background staining was markedly weaker than with antibody code 582005 (Ab 4) from the same firm. Just as with hTERT scores of Ab 2 (code EST21-A), however, values with Ab 6 were much lower than those with other antibodies (Figs. 1 and 3).

Viewing critically our immunohistochemical results for hTERT expression in BCC tissues we shall verify our experimental procedure with a larger patient population. According to proposals put forwarded by Tao et al (105) it might be regarded for an adjuvant hTERT-targeted therapy. In the first clinical trials by Mavroudis et al (106) and Bolonaki et al (107) the introduction of the TERT (572y)peptides was put to practice. In a clinical phase I/II study Brunsvig et al (108) tested two hTERT vaccines (GV1001 against hTERT sequence 611-626 and HR2822 against hTERT sequence 540-548): 12 of 24 patients and in addition, two patients after booster injections developed an immune reaction. The authors suggested that further clinical studies were warranted to evaluate this hTERT-based vaccination. After evaluation of all studies carried out so far with the hTERT 540-548-peptide Wenandy et al (109) gave notice that, despite contradictory outcomes, this peptide can be a target for tumor lysis therapy. Moreover, for assessment of their adjuvant BCG immunotherapy antibody NCl-hTERT (our Ab 3) was applied for evidence of hTERT as a therapeutical mark in patients with bladder carcinoma (97). 


\section{Acknowledgements}

We thank Mrs. C. Aubel for language editing and Mr. F. Hafner for the foto scanning. The study was supported by grants from the Berlin Sparkasse Foundation for Medicine.

\section{References}

1. English DR, Kricker A, Heenan PJ, Randell PL, Winter MG and Armstrong BK: Incidence of non-melanocytic skin cancer in Geraldton, Western Australia. Int J Cancer 73: 629-633, 1997.

2. Harris RB, Griffith K and Moon TE: Trends in the incidence of nonmelanoma skin cancers in Southeastern Arizona, 1985-1996. J Am Acad Dermatol 45: 528-536, 2001.

3. Koh D, Wang H, Lee J, Chia KS, Lee HP and Goh CL: Basalcell carcinoma, squamous-cell carcinoma and melanoma of the skin: analysis of the Singapore cancer registry data 1968-97. Br J Dermatol 148: 1161-1166, 2003.

4. Katalinic A, Kunze U and Schäfer T: Epidemiology of cutaneous melanoma and non-melanoma skin cancer in SchleswigHolstein, Germany: incidence, clinical subtypes, tumour stages and localization (epidemiology of skin cancer). Br J Dermatol 149: 1200-1206, 2003

5. Roewert-Huber J, Lange-Asschenfeldt B, Stockfleth E and Kerl H: Epidemiology and aetiology of basal cell carcinoma. Br J Dermatol 157: 47-51, 2007.

6. Lear W, Dahlke E and Murray CA: Basal cell carcinoma: review of epidemiology, pathogenesis, and associated risk factors. J Cutan Med Surg 11: 19-30, 2007.

7. Epstein EH: Basal cell carcinomas: attack of the hedgehog. Nat Rev Cancer 8: 743-754, 2008.

8. Kyrgidis A, Tzellos TG, Vahtsevanos K and Triaridis S: New concepts for basal cell carcinoma. Demographic, clinical, histological risk factors, and biomarkers. A systematic review of evidence regarding risk for tumor development, susceptibility for second primary and recurrence. J Surg Res (In press).

9. Leiter $U$ and Garbe C: Epidemiology of melanoma and nonmelanoma skin cancer - the role of sunlight. Adv Exp Med Biol 624: 89-103, 2008.

10. McGuire JF, Ge NN and Dyson S: Nonmelanoma skin cancer of the head and neck. I. Histopathology and clinical behavior. Am J Otolaryngol 30: 121-133, 2009.

11. Quinn AG: Ultraviolet radiation and skin carcinogenesis. Br J Hosp Med 58: 261-264, 1997.

12. English DR, Armstrong BK, Kricker A and Fleming C: Sunlight and cancer. Cancer Causes Control 8: 271-283, 1997.

13. Ouhtit A and Ananthaswamy HN: A model for UV-induction of skin cancer. J Biomed Biotechnol 1: 5-6, 2001.

14. Seidl H, Kreimer-Erlacher H, Bäck B, Soyer HP, Höfler G, Kerl H and Wolf P: Ultraviolet exposure as the main initiator of p53 mutations in basal-cell carcinomas from psorialen and ultraviolet A-treated patients with psoriasis. J Invest Dermatol 117: 365-370, 2001.

15. Hussein MR: Ultraviolet radiation and skin cancer: molecular mechanisms. J Cutan Pathol 32: 191-205, 2005.

16. Greinert R: Skin cancer: new markers for better prevention. Pathobiology 76: 64-81, 2009.

17. Sander CS, Hamm F, Elsner P and Thiele JJ: Oxidative stress in malignant melanoma and non-melanoma skin cancer. Br J Dermatol 148: 913-922, 2003.

18. Brash DE, Rudolph JA, Simon JA, Lin A, McKenna GJ, Baden HP, Halperin A J and Ponten $\mathrm{J}$ : A role for sunlight in skin cancer: UV-induced p53 mutations in squamous-cell carcinoma. Proc Natl Acad Sci USA 88: 10124-10128, 1991.

19. Ouhtit A, Nakazawa H, Armstrong BK, Kricker A, Tan E, Yamasaki H and English DR: UV-radiation-specific p53 mutation frequency in normal skin as a predictor of risk of basal-cell carcinoma. J Natl Cancer Inst 90: 523-531, 1998.

20. Liang SB, Ohtsuki Y, Furihata M, Takeuchi T, Iwata J, Chen BK and Sonobe H: Sun-exposure- and aging-dependent p53 protein accumulation results in growth advantage for tumour cells in carcinogenesis of nonmelanocytic skin cancer. Virchows Arch 434: 193-199, 1999.

21. Bolshakov S, Walker CM, Strom SS, Selvan MS, Clayman GL, El-Naggar A, Lippman SM, Kripke ML and Ananthaswamy HN: P53 mutations in human aggressive and nonaggressive basal and squamous-cell carcinomas. Clin Cancer Res 9: 228-234, 2003.
22. Marrot L and Meunier JR: Skin DNA photodamage and its biological consequences. J Am Acad Dermatol 58: S139-S148, 2008.

23. Ueda M, Ouhtit A, Bito T, Nakazawa K, Lübbe J, Ichihashi M, Yamasaki $\mathrm{H}$ and Nakazawa $\mathrm{H}$ : Evidence for UV-associated activation of telomerase in human skin. Cancer Res 57: 370-374, 1997.

24. Fabricius EM, Bezeluk A, Kruse-Boitschenko U, Wildner GP and Klein M: Clinical significance of telomerase activity in basal cell carcinomas and in tumour-free surgical margins. Int J Oncol 23: 1389-1399, 2003.

25. Park HR, Min SK, Cho HD, Kim KH, Shin HS and Park YE: Expression profiles of p63, p53, surviving, and hTERT in skin tumors. J Cutan Pathol 31: 544-549, 2004.

26. Fabricius E-M: Molecular mechanisms of basal cell and squamous cell carcinomas. In: The Role of Telomerase for Cancerogenesis of Basal Cell and Squamous Cell Carcinomas. Reichrath J (ed). Landes Bioscience and Springer Science + Bisness Media Inc., New York, pp115-133, 2006.

27. Burnworth B, Arendt S, Muffler S, Steinkraus V, Brocker EB, Birek C, Hartschuh W, Jauch A and Boukamp P: The multi-step process of human skin carcinogenesis: a role for p53, cyclin D1, hTERT, p16, and TSP-1. Eur J Cell Biol 86: 763-780, 2007.

28. Slaughter D, Southwick H and Smejkal W: 'Field cancerization' in oral stratified squamous epithelium. Cancer 6: 963-968, 1953.

29. Mertens F, Heim S, Mandahl N, Johansson B, Mertens O, Persson B, Salemark L, Wennerberg J, Jonsson N and Mitelman F: Cytogenetic analysis of 33 basal cell carcinomas. Cancer Res 51: 954-957, 1991.

30. Kanjilal S, Strom SS, Clayman GL, Weber RS, El-Naggar AK, Kapur V, Cummings KK, Hill LA, Spitz MR, Kripke ML and Ananthaswamy HN: p53 mutations in nonmelanoma skin cancer of the head and neck: molecular evidence for field cancerization. Cancer Res 55: 3604-3609, 1995.

31. Stern R, Bolshakov S, Nataraj A and Ananthaswamy H: p53 mutation in nonmelanoma skin cancers occurring in psoralen ultraviolet A-treated patients: evidence for heterogeneity and field cancerization. J Investig Dermatol 119: 522-526, 2002.

32. Sidoroff A: Photodynamische Therapie bei epithelialen Hauttumoren. Evidenzbasierte Datenlage. Hautarzt 58: 577-584, 2007.

33. Ponten F, Berg C, Ahmadian A, Ren Z, Nister M, Lundeberg J, Uhlen M and Ponten J: Molecular pathology in basal cell cancer with p53 as a genetic marker. Oncogene 15: 1059-1067, 1997.

34. Brennan P, Umar T, Bowden J, Hobkirk A, Spedding A, Conroy B, Zaki G and Macpherson D: Nitric oxide synthase expression is downregulated in basal cell carcinoma of the head and neck. $\mathrm{Br}$ J Oral Maxillofac Surg 38: 633-636, 2000.

35. Demirkan N, Colakoglu N and Duzcan E: Value of p53 protein in biological behavior of basal cell carcinoma and in normal epithelia adjacent to carcinomas. Pathol Oncol Res 6: 272-274, 2000.

36. Aiad HA and Hanout HM: Immunohistochemical Expression of CD10 in Cutaneous Basal and Squamous Cell Carcinomas. J Egypt Natl Cancer Inst 19: 195-201, 2007.

37. Kim N, Piatyszek M, Prowse K, Harley C, West M, Ho P, Coviello G, Wright W, Weinrich S and Shay J: Specific association of human telomerase activity with immortal cells and cancer. Science 266: 2011-2015, 1994.

38. Taylor R, Ramirez R, Ogoshi M, Chaffins M, Piatyszek M and Shay J: Detection of telomerase activity in malignant and nonmalignant skin conditions. J Invest Dermatol 106: 759-765, 1996.

39. Shay J and Bacchetti S: A survey of telomerase activity in human cancer. Eur J Cancer 33: 787-791, 1997.

40. Parris C, Jezzard S, Silver A, MacKie R, McGregor J and Newbold R: Telomerase activity in melanoma and non-melanoma skin cancer. Br J Cancer 79: 47-53, 1999.

41. Wu A, Ichihashi M and Ueda M: Correlation of the expression of human telomerase subunits with telomerase activity in normal skin and skin tumors. Cancer 86: 2038-2044, 1999.

42. Dhaene K, van Marck E and Parwaresch R: Telomeres, telomerase and cancer: an up-date. Virchows Arch 437: 1-16, 2000.

43. Ueda M: Telomerase in cutaneous carcinogenesis. J Dermatol Sci 23: S37-S40, 2000.

44. Kim B-C, Ryoo Y-W and Lee K-S: Telomerase activity in squamous cell carcinoma and basal cell carcinoma. Korean J Investigativ Dermatol 7: 184-187, 2000. 
45. Chen Z, Smith K, Skelton HG 3rd, Barrett T, Greenway HJ and Lo S: Telomerase activity in Kaposi's sarcoma, squamous cell carcinoma, and basal cell carcinoma. Exp Biol Med (Maywood) 226: 753-757, 2001

46. Dicker T, Siller G and Saunders N: Molecular and cellular biology of basal cell carcinoma. Australas J Dermatol 43: 241-246, 2002.

47. Hu S, Chan HL, Chen MC and Pang JH: Telomerase expression in benign and malignant skin neoplasms: comparison of three major subunits. J Formos Med Assoc 101: 593-597, 2002.

48. Boldrini L, Loggini B, Gisfredi S, Zucconi Y, Di Quirico D, Biondi R, Cervadoro G, Barachini P, Basolo F, Pingitore R and Fontanini G: Evaluation of telomerase in non-melanoma skin cancer. Int J Mol Med 11: 607-611, 2003.

49. Bezeluk A: Bestimmung der Telomeraseaktivität in Basalzellkarzinom-Geweben und in Basalzellkarzinom-freien Tumorrandgeweben des Kopf-Hals-Bereichs in der PCR unter dem Aspekt der prognostischen Aussage. Dissertation der medizinischen Fakultät der Humboldt-Universität Berlin. pp1133, 2005.

50. Saleh S, Lam AK, Buettner GP, Glasby M, Raasch B and Ho YH: Telomerase activity of basal cell carcinoma in patients living in North Queensland, Australia. Hum Pathol 38: 1023-1029, 2007.

51. Han J, Qureshi AA, Prescott J, Guo Q, Ye L, Hunter DJ and De Vivo I: A prospective study of telomere length and the risk of skin cancer. J Invest Dermatol 129: 415-421, 2009.

52. Fabricius E-M, Kruse-Boitschenko U, Khoury R, Wildner G-P, Raguse J-D and Klein M: Immunohistochemical determination of the appropriate anti-hTERT antibodies for in situ detection of telomerase activity in frozen sections of head and neck squamous cell carcinomas and tumor margin tissues. Int J Oncol 34: 1257-1279, 2009.

53. Soyer HP: Trichoblastic carcinoma. In: Neoplasms with follicular differentiation, Chapter 23. Ackerman AB, Reddy VB and Soyer HP (eds). Ardor Scribendi, USA, pp625-1007, 2001.

54. Rippey JJ: Why classify basal cell carcinomas? Histopathology 32: 393-398, 1998.

55. Wittekind Ch, Meyer HJ and Bootz F (eds): TNM Klassifikation maligner Tumoren. UICC International Union Against Cancer 6. Aufl. Korr. Nachdruck. Kopf- und Halstumoren, pp19-52, 2005.

56. Cordell JL, Falini B, Erber WN, Ghosh AK, Abdulaziz Z, MacDonald S, Pulford KAF, Stein H and Mason DY: Immunoenzymatic labeling of monoclonal antibodies using immune complexes of alkaline phosphatase and monoclonal anti-alkaline phosphatase (APAAP complexes). J Histochem Cytochem 32: 219-229, 1984

57. Fabricius E-M, Langford A, Bier J, Hell B, Wildner G-P and Blümcke S: Immunohistochemical characterization of E48 and CD44-v6 expression in head and neck carcinomas. Cancer J 10: 325-330, 1997

58. Fabricius E-M, Guschmann M, Wildner G, Langford A, Hell B and Bier J: Divergent immunohistochemical E48 and CD44-v6 antigen expression patterns between lymph node metastases and primary squamous cell carcinomas in the head and neck region. Cancer J 11: 325-330, 1998.

59. Fabricius E-M, Guschmann M, Langford A, Hell B and Bier J: Immunhistochemical assessment of the tumour-associated epitopes CD44v6 and E48 in tumour-free lymph nodes from patients with squamous cell carcinoma in the head-neck region. Anal Cell Pathol 20: 115-129, 2000.

60. Hiyama K, Hirai Y, Kyoizumi S, Akiyama M, Hiyama E, Piatyszek M-A, Shay J-W, Ishioka S and Yamakido M: Activation of telomerase in human lymphocytes and hematopoietic progenitor cells. J Immunol 155: 3711-3715, 1995.

61. Yamada O, Motoji T and Mizoguchi H: Up-regulation of telomerase activity in human lymphocytes. Biochim Biophys Acta 1314: 260-266, 1996.

62. Fabricius E-M, Gurr U and Wildner G-P: Telomerase activity levels in the surgical margin and tumour distant tissue of the squamous cell carcinoma of the head-and-neck. Anal Cell Pathol 24: 25-39, 2002.

63. Gurr U: Der Nachweis der Telomeraseaktivierung in Tumorgeweben und dem Tumor benachbarten Geweben von Plattenepithelkarzinomen im Kopf-Hals-Bereich. Dissertation der medizinischen Fakultät der Humboldt-Universität Berlin. pp1-106, 2003.

64. Wu YL, Dudognon C, Nguyen E, Hillion J, Pendino F, Tarkanyi I, Aradi J, Lanotte M, Tong JH, Chen GQ and Segal-Bendirdjian E: Immunodetection of human telomerase reverse-transcriptase (hTERT) re-appraised: nucleolin and telomerase cross paths. J Cell Sci 119: 2797-2806, 2006
65. Remmele W, Hildebrand U, Hienz HA, Klein P-J, Vierbuchen M, Behnken LJ, Heicke B and Scheidt E: Comparative histological, histochemical, immunohistochemical and biochemical studies on oestrogen receptors, lectin receptors, and Barr bodies in human breast cancer. Virchows Arch A Pathol Anat Histopathol 409: 127-147, 1986.

66. Remmele W und Stegner HE: Vorschlag zur einheitlichen Definition eines immunreaktiven Score (IRE) für den immunhistochemischen Östrogenrezeptor-Nachweis (ER-ICA) im Mammagewebe. Pathologie 8: 138-140, 1987.

67. Diehl JM und Staufenbiel T: Statistik mit SPSS für Windows Version 15. Verlag Dietmar Klotz, Eschborn, pp720, 2007.

68. Wernicke KD: Medizinische Biometrie - Planung und Auswertung medizinischer Studien - Skriptum zur Lehrveranstaltung 'Biomathematik/Biometrie' für Humanmediziner. Institut für Medizinische Biometrie, Universitätsklinikum Charité, Berlin, p126, 2003

69. Sachs L: Angewandte Statistik - Anwendung statistischer Methoden. 11. Auflage Springer Verlag, Berlin, p889, 2004.

70. Brasanac D, Boricic I, Todorovic V and Tomanovic N: Primary cutaneous carcinosarcoma: case report with expanded immunohistochemical analysis. Int J Dermatol 47: 496-501, 2008.

71. Perrem K, Lynch A, Al Nooh F, Leader M and Kay E: The different telomere lengths in basal and squamous cell carcinomas also differ between the nontransplant and renal transplant population. Hum Pathol 39: 1034-1041, 2008.

72. Guttman-Yassky E, Bergman R, Manov L, Sprecher E, Shaefer Y and Kerner H: Human telomerase RNA component expression in Spitz nevi, common melanocytic nevi, and malignant melanomas. J Cutan Pathol 29: 341-346, 2002.

73. Yan P, Benhattar J, Seelentag W, Stehle JC and Bosman FT: Immunohistochemical localization of hTERT protein in human tissues. Histochem Cell Biol 121: 391-397, 2004.

74. Hiyama E, Hiyama K, YokoyamaT and Shay JW: Immunohistochemical detection of telomerase (hTERT) protein in human cancer tissues and a subset of cells in normal tissues. Neoplasia 3: 17-26, 2001.

75. Poremba C, Hero B, Heine B, Scheel C, Schaefer K-L, Christiansen H, Berthold F, Kneif S, Stein H, Juergens H, Boecker W and Dockhorn-Dworniczak B: Telomerase is a strong indicator for assessing the proneness to progression in neuroblastomas. Med Pediatr Oncol 35: 651-655, 2000.

76. Poremba C, Scheel C, Hero B, Christiansen H, Schaefer KL, Nakayama J, Berthold F, Juergens H, Boecker W and Dockhorn-Dworniczak B: Telomerase activity and telomerase subunits gene expression patterns in neuroblastoma: a molecular and immunohistochemical study establishing prognostic tools for fresh-frozen and paraffin-embedded tissues. J Clin Oncol 18: 2582-2592, 2000.

77. Poremba C, Heine B, Diallo R, Heinecke A, Wai D, Schaefer K-L, Braun Y, Schuck A, Lanvers C, Bànkfalvi Â, Kneif S, Torhorst J, Zuber M, Köchli OR, Mross F, Dieterich H, Sauter G, Stein H, Fogt $\mathrm{F}$ and Boecker W: Telomerase as a prognostic marker in breast cancer: high-throughput tissue microarray analysis of hTERT and hTR. J Pathol 198: 181-189, 2002

78. Taylor CR, Shi SR, Chen C, Young L, Yang C and Cote RJ: Comparative study of antigen retrieval heating methods: microwave, microwave and pressure cooker, autoclave, and steamer. Biotech Histochem 71: 263-270, 1996.

79. Kleinschmidt K: Inaugural-Dissertation zur Erlangung des Grades einer Doktorin der Veterinärmedizin (Dr. med. vet.) durch die Tierärztliche Hochschule Hannover: Untersuchung von Endostatin freisetzenden Stammzellimplantaten zur Behandlung des Glioblastoms im Rattenmodell, pp1-207, 2006.

80. Yang Y, Chen Y, Zhang C, Huang $\mathrm{H}$ and Weissman SM: Nucleolar localization of hTERT protein is associated with telomerase function. Exper Cell Res 277: 201-209, 2002.

81. Ogoshi M, Le T, Shay J and Taylor R: In situ hybridization analysis of the expression of human telomerase RNA in normal and pathologic conditions of the skin. J Invest Dermatol 110: 818-823, 1998.

82. Luzar B, Poljak M and Gale N: Telomerase catalytic subunit in laryngeal carcinogenesis - an immunohistochemical study. Mod Pathol 18: 406-411, 2005.

83. Volpi A, Bravaccini S, Medri L, Cerasoli S, Gaudio M and Amadori D: Usefulness of immunological detection of the human telomerase reverse transcriptase. Cell Oncol 27: 347-353, 2005.

84. Broccoli D, Young JW and de Lange T: Telomerase activity in normal and malignant hematopoietic cells. Proc Natl Acad Sci USA 92: 9082-9086, 1995. 
85. Bodnar AG, Kim NW, Effros RB and Chiu CP: Mechanism of telomerase induction during $\mathrm{T}$ cell activation. Exp Cell Res 228: 58-64, 1996.

86. Shay JW and Wright WE: Telomerase activity in human cancer. Curr Opin Oncol 8: 66-71, 1996.

87. Kaur P, Mulvaney M and Carlson JA: Basal cell carcinoma progression correlates with host immune response and stromal alterations: a histologic analysis. Am J Dermatopathol 28: 293-307, 2006.

88. Lantuejoul S, Salon C, Soria J-C and Brambilla E: Mini review: telomerase expression in lung preneoplasia and neoplasia. Int $\mathrm{J}$ Cancer 120: 1835-1841, 2007.

89. Lam AK, Ong K and Ho YH: hTERT expression in colorectal adenocarcinoma: correlations with p21, p53 expressions and clinicopathological features. Int J Colorectal Dis 23: 587-594, 2008.

90. Cassaro M, Rugge M, Tieppo C, Giacomelli L, Velo D, Nitti D and Farinati $\mathrm{F}$ : Indefinite for non-invasive neoplasia lesions in gastric intestinal metaplasia: the immunophenotype. J Clin Pathol 60: 615-621, 2007.

91. Olsen SH, Su LD, Thomas D and Fullen DR: Telomerase expression in sebaceous lesions of the skin. J Cutan Pathol 34: 386-391, 2007.

92. Zendehrokh N, Rehnberg J and Dejmek A: Comparison of NCL-hTERT antibody reactivity and telomere repeat amplification protocol in situ in effusions. Acta Cytol 51: 886-892, 2007.

93. Yang CH, Hung WC, Wang SL, Kang WY, Chen WT, Huang YC, $\mathrm{Su}$ YC and Chai CY: Immunoexpression and prognostic role of hTERT and cyclin D1 in urothelial carcinoma. APMIS 116: 309-316, 2008.

94. Forsyth R, De Boeck G, Bekaert S, De Meyer T, Taminiau A, Uyttendaele D, Roels H, Praet M and Hogendoorn P: Telomere biology in giant cell tumour of bone. J Pathol 214: 555-563, 2008.

95. Tabori U, Wong V, Ma J, Shago M, Alon N, Rutka J, Bouffet E, Bartels U, Malkin D and Hawkins C: Telomere maintenance and dysfunction predict recurrence in paediatric ependymoma. Br J Cancer 99: 1129-1135, 2008.

96. Tantbirojn $\mathrm{P}$, Triratanachat $\mathrm{S}$, Trivijitsilp $\mathrm{P}$ and Niruthisard $\mathrm{S}$ : Human telomerase reverse transcriptase (hTERT) expression in borderline ovarian tumors: an immunohistochemical study. J Med Assoc Thai 92: 308-314, 2009.

97. Zachos I, Konstantinopoulos PA, Vandoros GP, Karamouzis MV, Papatsoris AG, Podimatas T, Papachristodoulou A, Chrisofos M, Deliveliotis C and Papavassiliou AG: Predictive value of telomerase reverse transcriptase expression in patients with high risk superficial bladder cancer treated with adjuvant BCG immunotherapy. J Cancer Res Clin Oncol 135: 1169-1175, 2009.

98. Mitsuishi T, Nakatake M, Kaneko T, Ohara K, Kato T, Iida K, Iwabu Y, Tokunaga K, Sata T, Kawana S and Yamada O: Evaluation of telomerase activity in non-genital Bowen's disease. J Eur Acad Dermatol Venereol 23: 668-672, 2009.
99. Ridley L, Rahman R, Brundler MA, Ellison D, Lowe J, Robson K, Prebble E, Luckett I, Gilbertson RJ, Parkes S, Rand V, Coyle B, Grundy RG and on behalf of the Children's Cancer and Leukaemia Group Biological Studies Committee: Multifactorial analysis of predictors of outcome in pediatric intracranial ependymoma. Neuro Oncol 10: 675-689, 2008.

100. Khurts S, Masutomi K, Delgermaa L, Arai K, Oishi N, Mizuno H, Hayashi N, Hahn WC and Murakami S: Nucleolin interacts with telomerase. J Biol Chem 279: 51508-51515, 2004.

101. Hiyama E and Hiyama K: Telomerase as tumor marker. Cancer Lett 194: 221-233, 2003.

102. Hiyama E and Hiyama K: Telomerase detection in the diagnosis and prognosis of cancer. Cytotechnology 45: 61-74, 2004.

103. Miyazu YM, Miyazawa T, Hiyama K, Kurimoto N, Iwamoto Y, Matsuura H, Kanoh K, Kohno N, Nishiyama M and Hiyama E: Telomerase expression in noncancerous bronchial epithelia is a possible marker of early development of lung cancer. Cancer Res 65: 9623-9627, 2005

104. Hashimoto Y, Murakami Y, Uemura K, Hayashidani Y, Sudo T, Ohge H, Fukuda E, Sueda T and Hiyama E: Detection of human telomerase reverse transcriptase (hTERT) expression in tissue and pancreatic juice from pancreatic cancer. Surgery 143: 113-125, 2008.

105. Tao Z, Chen S, Wu Z, Xiao B, Liu J and Hou W: Targeted therapy of human laryngeal squamous cell carcinoma in vitro by antisense oligonucleotides directed against telomerase reverse transcriptase mRNA. J Laryngol Otol 119: 92-96, 2005.

106. Mavroudis D, Bolonakis I, Cornet S, Myllaki G, Kanellou P, Kotsakis A, Galanis A, Nikoloudi I, Spyropoulou M, Menez J, Miconnet I, Niniraki M, Cordopatis P, Kosmatopoulos K and Georgoulias V: A phase I study of the optimized cryptic peptide TERT $(572 y)$ in patients with advanced malignancies. Oncology 70: 306-314, 2006.

107. Bolonaki I, Kotsakis A, Papadimitraki E, Aggouraki D, Konsolakis G, Vagia A, Christophylakis C, Nikoloudi I, Magganas E, Galanis A, Cordopatis P, Kosmatopoulos K, Georgoulias V and Mavroudis D: Vaccination of patients with advanced non-small-cell lung cancer with an optimized cryptic human telomerase reverse transcriptase peptide. J Clin Oncol 25: 2727-2734, 2007.

108. Brunsvig PF, Aamdal S, Gjertsen MK, Kvalheim G Markowski-Grimsrud CJ, Sve I, Dyrhaug M, Trachsel S, Møller M, Eriksen JA and Gaudernack G: Telomerase peptide vaccination: a phase I/II study in patients with non-small cell lung cancer. Cancer Immunol Immunother 55: 1553-1564, 2006.

109. Wenandy L, Sørensen RB, Sengeløv L, Svane IM, Thor Straten P and Andersen MH: The immunogenicity of the hTERT540-548 peptide in cancer. Clin Cancer Res 14: 4-7, 2008. 